Article

\title{
The Evolving Common Law Jurisprudence Combatting the Threat of Terrorism in the United Kingdom, United States, and Canada
}

\author{
James C. Simeon
}

Head of McLaughlin College, Associate Professor, School of Public Policy and Administration, York University, 224 McLaughlin College, 4700 Keele Street, Toronto, ON M3J 1P3, Canada; jcsimeon@yorku.ca

Received: 13 October 2018; Accepted: 1 February 2019; Published: 14 February 2019

\begin{abstract}
Terrorism is a concept that defies a simple and straightforward legal definition. Therefore, it is not surprising to find that there is no Comprehensive Convention on Terrorism with a universally accepted definition of what constitutes "terrorism." Consequently, States have devised their own definitions of what constitutes terrorism that are typically found in their criminal law. This raises the fundamental question of whether there is a convergence or divergence in jurisprudential trends on what constitutes terrorism among States? Presumably, a convergence in jurisprudential trends is more likely to contribute to combatting the threat of terrorism at the international and national levels. Accordingly, this article comparatively analyzes the definition of terrorism in three common law jurisdictions: the United Kingdom, the United States, and Canada. It finds that although there are a number of similarities in the definition of terrorism in these three States, they have significantly different definitions of what constitutes terrorism. The UK definition, ostensibly, has the broadest definition of terrorism of the three States. The US has, undoubtedly, the most unique, with separate definitions for "international terrorism" and "domestic terrorism." Additionally, Canada has the most international definition of terrorism, drawing on 13 functional terrorism Conventions to define offenses such as hijacking, hostage taking, and bombing, etc. The second part of the article comparatively analyzes seven of the leading Supreme Court cases on terrorism in these three States. From the ratio or rationes decidendi in each of these cases, it draws out the twelve legal principles that underlie these judgements and finds that they are similar and overall consistent. The conclusion reached is that there is, at least in these three common law jurisdictions, an apparent convergence in jurisprudential trends in the law of terrorism. This augurs well for the development and emergence of a common definition of what constitutes terrorism at the international and transnational levels, as well as more rigorous and effective counter-terrorism laws and policies within and across States.
\end{abstract}

Keywords: terrorism; terrorism law; defining terrorism; comparative legal analysis; common law jurisdictions; leading superior court judgements; comparative jurisprudential analysis; ratio or rationes decidendi; legal principles; jurisprudential trends

\section{Introduction}

Terrorism is a concept that defies a simple and straightforward legal definition. This is perhaps most evident from the voluminous legal literature on terrorism. ${ }^{1}$ Ben Saul has noted that "Few words are plagued by so much indeterminacy, subjectivity, and political disagreement as 'terror',

1 Consider the following as examples: (Terrorism Research n.d.; Justice Canada 2015; Allyson 2012). (Roser and Nagdy 2016); Nicholas J. Perry states that "The scholarly literature on terrorism is 'vast and ever expanding.'” in (Perry 2004). 
'terrorize', 'terrorism', and 'terrorist'."' The famous aphorism that "one person's terrorist is another person's freedom fighter," encapsulates the essence of defining what is inherently perceived to be the fundamental "political" nature of terrorism. Therefore, it is not surprising to find that there is no universally accepted definition of terrorism and that States have devised their own definitions of terrorism that are typically found in their criminal law. The importance and relevance of developing a common definition for what constitutes terrorism should be self-evident. ${ }^{3}$ Legal principle demands that there be certainty in the law with respect to crimes and their penalties. There should be no doubt or ambiguity with respect to what constitutes a crime of terrorism, prior to its alleged commission.

Human history has amply demonstrated that the use of extreme violence, in the form of terrorism, to advance any cause, no matter how seemingly meritorious, noble, or necessary, is not only highly devastating and destructive, but diminishes and undermines the very ends that it seeks to achieve. ${ }^{4}$ The use of terrorism, in any of its variants, such as State-sponsored terrorism, religious terrorism, right or left-wing terrorism, and cyberterrorism, ${ }^{5}$ is morally wrong and condemns all those who espouse and/or practice it. ${ }^{6}$

The absence of a comprehensive and universal definition of terrorism has made it more difficult to undertake effective counter-terrorism strategies and policies at both the international and transnational levels. ${ }^{7}$ The development of a consensus of what terrorism is and how it ought to be defined is essential to combatting terrorism in all its manifestations. ${ }^{8}$

Various criticisms have been levelled at States for having legislated vague and over-broad definitions of terrorism. The attendant effect could lead to an "abuse of power" by the State. ${ }^{9}$ The way that the term terrorism is defined can have "a vital effect in determining the overall scope and application of an anti-terrorism law regime." 10 The legislative basis on how the term "terrorism" is defined affects how the courts will apply and interpret the term to the factual situation of any case before them. In common law jurisdictions, it is both the statute and the court's interpretation of the statute that shape the law at any given time.

Accordingly, this article will first examine and comparatively analyze the manner in which the term terrorism is defined in the most recent relevant legislation within three common law jurisdictions: the United Kingdom (UK), the United States (US), and Canada. This will be followed with an examination of some of the most recent and relevant jurisprudence on the issue of terrorism by the Supreme Courts (SCs) of these leading common law jurisdictions. This is important and relevant because the SCs in each of these jurisdictions deal exclusively with the most pertinent and significant constitutional law issues that need to be resolved with respect to any legal matters arising within their court systems or that may be referenced to them by their Governments. Given the principle of stare decisis $^{11}$, the judgements of the SCs, in these common law jurisdictions, will determine how the law will be applied and interpreted by the lower courts and administrations within their States.

These three States have been selected not only because their legal systems are based on common law, but also because they all share common histories, cultures, and traditions. Not only are these countries close allies and partners in trade and commerce, but Canada and the United States originated

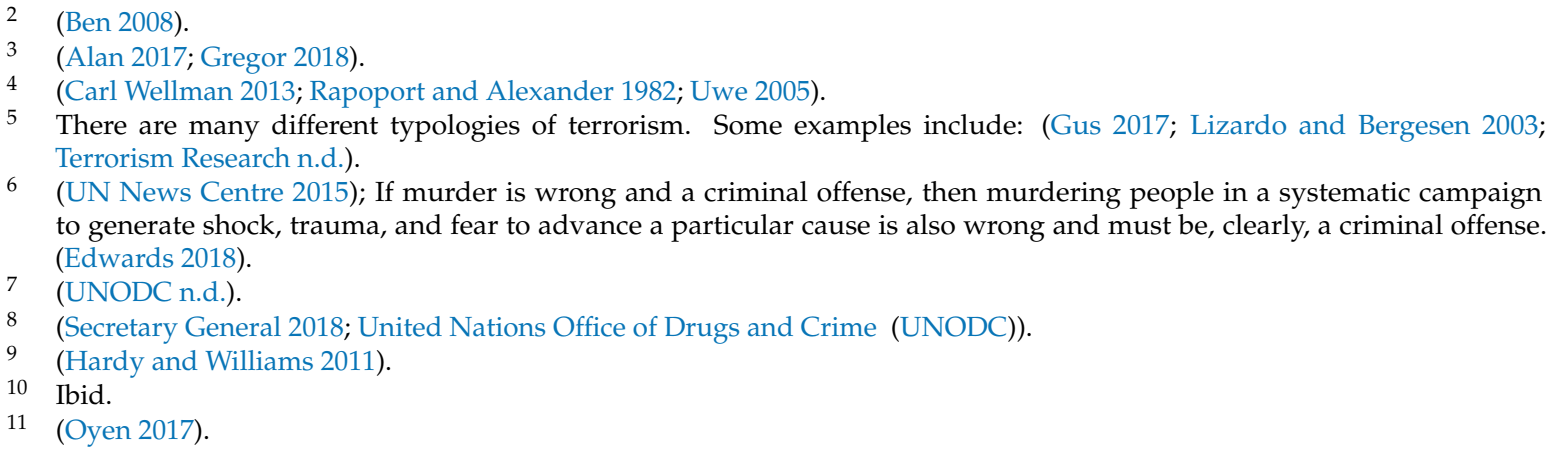


as colonies of Great Britain and, as a consequence, the three share many similarities. ${ }^{12}$ However, there are, of course, also important and significant differences. For example, the United Kingdom has a unitary parliamentary system of government without a codified constitution, whereas both Canada and the United States have federal parliamentary and congressional systems of government with written constitutions and with an entrenched Charter or Bills of Rights.

Geographically, of course, Canada and the United States are contiguous, sharing the world's longest undefended border, while the United Kingdom is within relative close proximity and together they constitute the famous North Atlantic Triangle. ${ }^{13}$ Hence, given all the commonalities and similarities, what impacts one of these countries will affect, inevitably, the others. This should help to facilitate the comparative legal analysis across jurisdictions, as well as provide greater confidence on any conclusions that are drawn from the findings of this comparative legal analysis. For the purposes of this article, it is important to stress that the judgements of the respective Supreme Courts are closely followed and, as a consequence, influence each other's judgements. ${ }^{14}$

The main argument presented is that despite the differences in the way terrorism is legally defined in these three jurisdictions, there is a common legal understanding of what constitutes terrorism and that the legal principles emerging from some of the leading terrorism jurisprudence are, overall, rather similar and consistent, which indicates that there appears to be a convergence in the criminal law on terrorism across these three States. This indicates that there is a greater potential for more consistent and effective counter-terrorism laws and policies across these three jurisdictions.

The main argument is presented in four parts. The first examines and comparatively analyzes the legal definitions of terrorism in the UK, the US, and Canada. The second examines and comparatively analyzes some of the superior courts' leading cases dealing with the definition and other aspects of terrorism in these three jurisdictions. The third part comparatively analyzes the principles of law that emerge from the ratio decidendi or the rationes decidendi of the seven terrorism judgements, employing two cases each from the UK and the US and three cases from Canada, and finds that they appear to comprise a coherent whole that points to a convergence of the criminal law on terrorism among these three States. (See Appendix A for the list of cases that are considered for each jurisdiction.) The article concludes with some reflections on the definition and the development of the criminal law on terrorism across these three jurisdictions. It also argues that these findings suggest that there is common ground, at least among these three States, for the development of a comprehensive universal definition of what constitutes terrorism on both an international and transnational law basis. Moreover, it augurs well for the development of more rigorous and effective counter-terrorism strategies and policies to combat terrorism, at least across these three States.

\section{Terrorism: Legal Definitions}

It is important to first begin by examining how terrorism is defined in each of these common law jurisdictions. Since there is no comprehensive universal definition of what constitutes terrorism, States are free to define terrorism as they deem appropriate. Consequently, the definition of terrorism differs across these three States.

12 (Granastein and Azzi 2015; Government of Canada 2016); For instance, for the close relationship between Canada and the United Kingdom, see, (Harper and Cameron 2011) Canada-United Kingdom Joint Declaration, A Strong Partnership for the 21st Century, 22nd of September 2011, Rt. Hon. Stephen Harper, MP, Prime Minister of Canada, and Rt. Hon. David Cameron, MP, Prime Minister of the United Kingdom of Great Britain and Northern Ireland, 2011.

13 (Brebner 1945; Brebner 1948; McCulloch 2008; McCulloch 2011).

14 It is important to note that the Province of Quebec in Canada and the State of Louisiana in the United States have a civil law tradition as they were originally colonies of France. However, for this study, only federal/national jurisdictions will be considered for the purposes of this comparative legal analysis. The main difference between common law jurisdictions and civil law jurisdictions is primarily the importance of case law, in the form of published judicial opinions, in common law jurisdictions, and codified statutes, that predominate in civil law jurisdictions. See (School of Law n.d.) The Robbins Collection, School of Law (Boalt Hall), University of California at Berkeley, The Common Law and Civil Law Traditions, undated. 


\subsection{The Legal Definition of the Crime of Terrorism in the UK}

The United Kingdom's Terrorism Act 2000 is quite comprehensive, with eight Parts and 16 Schedules. There are six Parts that deal specifically with terrorism, the seventh deals with Northern Ireland, and the eighth deals with "General" provisions. ${ }^{15}$ Part 1, Introductory, defines terrorism in the following terms:

1. Terrorism: interpretation.

(1) In this Act, "terrorism" means the use or threat of action where-

(a) the action falls within subsection (2),

(b) the use or threat is designed to influence the government [F1 or an international governmental organisation] or to intimidate the public or a section of the public, and

(c) the use or threat is made for the purpose of advancing a political, religious [F2, racial] or ideological cause. ${ }^{16}$

This first section of Part 1 states that terrorism means "the use or threat of action" that is intended to influence a government or international organization, or to intimate the public or a segment of the public at large for the purpose of advancing a political, religious, racial, or ideological cause. In short, it is the use or threat of use of extreme violence to advance a particular political, religious, racial, or ideological cause.

(2) Action falls within this subsection if it-

(a) involves serious violence against a person,

(b) involves serious damage to property,

(c) endangers a person's life, other than that of the person committing the action,

(d) creates a serious risk to the health or safety of the public or a section of the public, or

(e) is designed seriously to interfere with or seriously to disrupt an electronic system.

(3) The use or threat of action falling within subsection (2) which involves the use of firearms or explosives is terrorism whether or not subsection (1)(b) is satisfied. ${ }^{17}$

Terrorism, as outlined in section two, involves serious violence against a person or serious damage to property; endangers a person's life, health, or safety; or is intended to disrupt an electronic system. The common feature among all of these actions is they inflict "serious" violence on a person and damage to property and electronic systems. Section three qualifies the definition of terrorism further by including the use or threat of action that involves either firearms or explosives, even when subsection (1)(b) is not satisfied; that is, it is intended to influence the government or an international governmental organization or to intimidate the public or a segment of the public.

(4) In this section-

(a) "action" includes action outside the United Kingdom,

15 (legislation.gov.uk 2000) The Terrorism Act 2000 was amended in 2006 with the expansion of the number of offenses, penalties, and other miscellaneous provisions. However, there were only minor additions to the definition of terrorism in the Terrorism Act 2000 that are listed in section one, above, as F1 and F2. For the Terrorism Act 2006, see (legislation.gov.uk 2006). See also the Counter-Terrorism and Security Act, 2015 that includes further provisions regarding terrorism and additional amendments to the Terrorism Act 2000. (legislation.gov.uk 2015)

16 Ibid.

17 Ibid. 
(b) a reference to any person or to property is a reference to any person, or to property, wherever situated,

(c) a reference to the public includes a reference to the public of a country other than the United Kingdom, and;

(d) "the government" means the government of the United Kingdom, of a Part of the United Kingdom or of a country other than the United Kingdom. ${ }^{18}$

Section four addresses the geographical scope of terrorism that includes terrorist actions that also take place outside the United Kingdom. This is important because terrorism need not, of course, be solely domestic and, frequently involves international aspects and connections of various sorts.

(5) In this Act a reference to action taken for the purposes of terrorism includes a reference to action taken for the benefit of a proscribed organisation. ${ }^{19}$

Section five refers to proscribed organizations. Like Canada and the United States, the United Kingdom has its own list of terrorist organizations. ${ }^{20}$ Under the Terrorist Act 2000, there are 71 proscribed terrorist organizations. In addition, there are 14 other organizations in Northern Ireland that were proscribed under previous legislation. ${ }^{21}$

In summary, the definition of terrorism in the UK employs the means, intent, and motivation to develop the legal definition of what constitutes the crime of terrorism. It also involves the use of extreme or serious violence to advance its cause. This also includes the disruption of electronic systems or what has been referred to as "cyberterrorism." The use of firearms and explosives precludes the necessity of establishing the intent of influencing the government or an international governmental organization, or intimidating the public or section thereof.

Terrorism is also seen as a global phenomenon and not merely a problem that affects some States in the world community. Terrorism is not merely a domestic concern, but is now largely an international phenomenon and this is recognized in this definition. Finally, the UK tracks terrorist organizations and proscribes them in law and makes it a criminal offense to belong to, to assist, or to promote a proscribed organization. Like other jurisdictions, the UK has an elaborate process in place to identify and to proscribe terrorist organizations and a system to challenge these proscriptions. This is done in an effort to contain and to counteract the terrorist threat to the UK and abroad. ${ }^{22}$

It is also important and relevant to note that all three prongs of this legal definition must be made out to carry a criminal offense of terrorism: intent; motive; means; and, notably, irrespective of locus, within or outside the UK. As noted, belonging to or supporting a proscribed organization is a criminal offense that is subject to prosecution, with a maximum penalty of 10 years imprisonment and/or a fine.

With respect to the UK definition of terrorism, it has been observed that the "principle of normalcy" should be included in any special legislation dealing with terrorism because it is an important reminder that the fundamental lesson of 'the instrument of law' is that it should be proportionate. Otherwise, there is a danger that "Terrorism Acts will foster the very extremism they were meant to prevent." ${ }^{23}$

18 Ibid.

19 (legislation.gov.uk 2000) Terrorism Act 2000, 2000 Chapter 11.

20 (UK Home Office 2016a). Proscription makes it a criminal offence to belong to or to profess to belong to a proscribed organization in the UK or overseas; invite support for a proscribed organization; arrange, manage, or assist in arranging or managing a meeting that is intended to support the activities of a proscribed organization; and to wear clothing or to carry or to display articles in public in such a way or in such circumstances as to arouse suspicion that the individual is a member of a prescribed organization. The penalties for proscription offenses are a maximum of 10 years in prison and/or a fine.

21 Ibid., p. 5.

22 (UK Home Office 2016b).

23 (Walker 2008). 


\subsection{The Legal Definition of the Crime of Terrorism in the US}

Title 18 of the United States Code is the principal criminal code of the federal government of the United States. ${ }^{24}$ The extensive detailed statutory provisions dealing with terrorism are found in the U.S. Code, Title 18, Part I, Chapter 113B-Terrorism. ${ }^{25}$ Specifically, the definitions of the crime of terrorism are found in 18 U.S. Code $\$ 2331 .{ }^{26}$ Terrorism is divided into "international terrorism" activities and "domestic terrorism" activities and these feature separate definitions. The three components of the definition of "international terrorism" are offenses, intention, and geographical scope. Each component will be outlined in turn.

The definition of "terrorism" in 18 U.S. Code $\$ 2331$ states:

(A) involve violent acts or acts dangerous to human life that are a violation of the criminal laws of the United States or of any State, or that would be a criminal violation if committed within the jurisdiction of the United States or of any State;

The offenses identified here are violent or dangerous acts to human life that violate the criminal laws of both the federal US government and the State governments or a violation within the jurisdiction of the US or of any State. ${ }^{27}$ It is relevant to note that the definition of "international terrorism" covers the criminal code offenses in both the US federal and State jurisdictions, as follows:

(B) appear to be intended-

(i) to intimidate or coerce a civilian population;

(ii) to influence the policy of a government by intimidation or coercion; or

(iii) to affect the conduct of a government by mass destruction, assassination, or kidnapping, ${ }^{28}$

The intent, under this definition of "international terrorism," is patently self-evident. The terrorist activities are intended to intimidate or coerce the civilian population and the policy of a government through the means of mass destruction, assassination, or kidnapping.

The geographical basis of the definition is articulated as such:

(C) occur primarily outside the territorial jurisdiction of the United States, or transcend national boundaries in terms of the means by which they are accomplished, the persons they appear intended to intimidate or coerce, or the locale in which their perpetrators operate or seek asylum, ${ }^{29}$

The act of terrorism needs to have taken place "primarily outside the territorial jurisdiction of the United States or transcend national boundaries in terms of the means by which they are accomplished." ${ }^{30}$ What is interesting here is the specific reference to "the locale in which their

24 (Cornell University Law School 2018a). It is important to point out that the States in the United States also have their own criminal codes. See (Cornell University Law School n.d.). This article will only examine the federal criminal code and its definition of terrorism and not those of the US States.

25 (Cornell University Law School 2018b). There are many other definitions of terrorism in US federal statutes, such as section 212 (a)(3)(B) of the Immigration and Naturalization Act (8 U.S.C. § 1182(a)(3)(B)), or as defined in section 140(d)(2) of the Foreign Relations Authorization Act, Fiscal Years 1988 and 1989 (22 U.S.C. § 2656f(d)(2)). See also (U.S. Department of Justice, Office of Justice Programs, and National Institute of Justice NIJ). (U.S. Department of Justice, Office of Justice Programs, and National Institute of Justice NIJ). This study will only concentrate on the definition of terrorism that is found in Title 18 U.S. Code, Chapter 113B.

26 Cornell University Law School 2018c.

27 The phrase "or of any State" can be interpreted in a number of ways: all other States in the international community; the 50 States that comprise the United States of America; or, indeed, both. Either way, it encompasses a very broad and wide sweeping definition of what constitutes "terrorism". If it includes all States in the world community, then it would include the UK and Canadian definitions of terrorism that are examined in detail in this article. However, it is generally understood to mean the 50 States of the USA. See (Jenkins 2003).

28 (Cornell University Law School 2018c).

29 Ibid.

30 Ibid. 
perpetrators operate or seek asylum." It is not clear why there is a specific reference here to the perpetrators' place of operations or where they "seek asylum."

Associating asylum seekers with "international terrorism" is highly problematic because it casts a negative light on all asylum seekers. ${ }^{31}$ It suggests that the asylum system is being used by international terrorists to gain easy access to the United States. As it has been noted many times, the US has one of the most stringent security screening processes for asylum seekers in the world. Accordingly, as it has been pointed out many times, if a potential terrorist does not want to be detected, then they should not be using the asylum process to enter the United States. ${ }^{32}$ In this regard, it is also important to mention that the United States keeps its own list of Foreign Terrorist Organizations (FTOs), with some 61 designated FTOs on its list; that is mandated under section 219 of the Immigration and Nationality Act (INA). ${ }^{33}$ It is unlawful for a person in the US or who is subject to the jurisdiction of the US to knowingly provide "material support or resources" to designated FTOs. ${ }^{34}$ Representatives and members of designated FTOs, who are aliens, are inadmissible to and, in certain circumstances, are removable from the United States. ${ }^{35}$ Other purposes for designating FTOs are to stigmatize and isolate them within the international community and increase public awareness and knowledge of these terrorist organizations to help contain and limit their activities. ${ }^{36}$

The definition of "domestic terrorism" is nearly identical to the definition of "international terrorism," that incorporates the same three elements: offenses, intent, and geographic scope. The geographic locus of "domestic terrorism" is, obviously, restricted to "(C) occur[ring] primarily within the territorial jurisdiction of the United States." 37

It is not entirely evident why the United States makes an explicit distinction between "international and domestic" terrorism, when, more often than not, States combine these into a single definition where the terrorist activity may be either inside or outside the territorial boundaries or jurisdiction of the State. The fact that criminal law is a concurrent jurisdiction in the United States with criminal codes at both the federal and the State level could be a contributing factor for this type of distinction.

The US federal definition of terrorism distinguishes between "international and domestic" terrorism, which are virtually the same, except for the geographic scope, whereby "domestic terrorism" is limited to the territorial boundaries or the jurisdiction of the United States. The reference to asylum seekers is also unique, although seemingly uncalled for in the United States, given the intense security screening processes for those who are seeking asylum or refugee protection there. ${ }^{38}$

Nicholas J. Perry has noted that "the immigration consequences of the definitions for "terrorist activity" and "engage in terrorist activity" are significant." 39 They bar the alien from being admitted into the United States and serve as grounds of deportability for an alien who is otherwise lawfully in the country. Furthermore, it is important to note that a "determination that a person engaged in terrorist activity bars asylum, admission as a refugee, and most other immigration benefits." 40

What is apparently absent from the US federal definition of terrorism is the motivation of the perpetrators of such activities. There is no need to be politically motivated by either a political, religious, racial, or ideological cause to be captured within the US definition of either "international or domestic terrorism." Furthermore, the United States compiles a list of FTOs in order to screen out all aliens who are members of or who are associated in other ways with these FTOs.

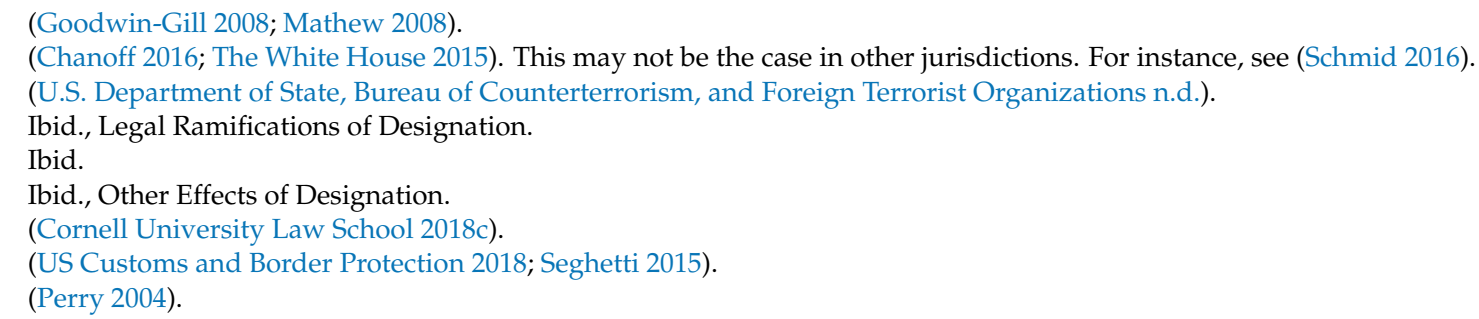


The American Civil Liberties Union (ACLU) opposes "the broad definition of terrorism and the ensuing authority that flows from that definition." 41 The ACLU argues that domestic terrorism could include acts which "cause serious physical injury or death", rather than all acts that are "dangerous to human life." By doing so, it argues, it will "exclude the conduct of organizations and individuals that engage in minor acts of property damage of violence." 42

\subsection{The Legal Definition of the Crime of Terrorism in Canada}

The legal definition of the crime of terrorism in Canada is found in the Canadian Criminal Code (R.S.C., 1985, c. C-46), Part II-1-Terrorism, Section 83.01. The provisions laid out therein are quite extensive, covering everything from the definition of terrorism to the financing of terrorism; the freezing, seizing and restraint, and the forfeiture of property; a hoax regarding terrorist activity; proceedings and aggravated punishment; investigative hearing; and recognizance and conditions. ${ }^{43}$

The legal definition of the crime of terrorism is broken down into two main parts: terrorist activity and terrorist group. Terrorist activity contains three principal elements: offenses, the motivation, and the intention. They include the following:

(a) an act or omission that is committed in or outside Canada and that, if committed in Canada, is one of the following offences: ${ }^{44}$

It then goes on to list the 13 functional Conventions and Protocols, negotiated under the auspices of the United Nations, against different types of terrorist acts. ${ }^{45}$

(b) an act or omission, in or outside Canada,

(i) that is committed

(A) in whole or in part for a political, religious or ideological purpose, objective or cause, and

(B) in whole or in part with the intention of intimidating the public, or a segment of the public, with regard to its security, including its economic security, or compelling a person, a government or a domestic or an international organization to do or to refrain from doing any act, whether the public or the person, government or organization is inside or outside Canada, and ${ }^{46}$

Section 83.01 (1)(b)(i)(A) and (B) are the motive clauses of the definition. The offenses listed in 83.01 (1)(a) must be committed, in whole or in part, with either a "political, religious or ideological purpose, objective or cause" and must, in whole or in part, be done with "the intention of intimidating the public or a segment of the public, with regard to its security or ... [to compel] a person, a government or a domestic or an international organization to do or to refrain from doing any act", whether they are inside or outside Canada.

Intention incorporates the following elements of section 83.01 (1)(b):

(ii) that intentionally

(A) causes death or serious bodily harm to a person by the use of violence,

\footnotetext{
(ACLU, American Civil Liberties Union 2018).

Ibid.

(Justice Laws Website 2018), Part II-1-Terrorism, Section 83.01.

Ibid., Section 83.01(1).

4 Ibid., 83.01(1)(a)(i)-(x). There are, in fact, 19 international instruments that have been negotiated under the auspices of the UN that deal with terrorism. See (UN Office of Counter-Terrorism n.d.).

46 (Justice Laws Website 2018), Part II-1-Terrorism, Section 83.01(1).
} 
(B) endangers a person's life,

(C) causes a serious risk to the health or safety of the public or any segment of the public,

(D) causes substantial property damage, whether to public or private property, if causing such damage is likely to result in the conduct or harm referred to in any of clauses (A) to (C), or

(E) causes serious interference with or serious disruption of an essential service, facility or system, whether public or private, other than as a result of advocacy, protest, dissent or stoppage of work that is not intended to result in the conduct or harm referred to in any of clauses (A) to (C), ${ }^{47}$

The intention is to cause death; serious bodily harm; serious risk to the health of the public or a segment of the public; severe property damage; and/or serious interference or serious disruption to an essential service, facility, or system, whether public or private. Section $83.01(1)(b)$ is qualified by the following condition:

and includes a conspiracy, attempt or threat to commit any such act or omission, or being an accessory after the fact or counselling in relation to any such act or omission, but, for greater certainty, does not include an act or omission that is committed during an armed conflict and that, at the time and in the place of its commission, is in accordance with customary international law or conventional international law applicable to the conflict, or the activities undertaken by military forces of a state in the exercise of their official duties to the extent that those activities are governed by other rules of international law. (activité terroriste) ${ }^{48}$

There are two important qualifications that are added to the definition of terrorist activity that include all those who may be complicit in these types of acts or omissions. This also includes inchoate offences of which the crime of "conspiracy" is a prime example. However, it excludes types of acts or omissions during an armed conflict that are in accordance with customary or conventional international law or that are undertaken by military forces of a State in the exercise of their official duties.

The "terrorist group" part of the definition of the crime of terrorism has two elements to its meaning: (a) an entity that has, as one of its purposes or activities, facilitating or carrying out any terrorist activity; or (b) a listed entity. ${ }^{49}$ The term "entity" is defined as "a person, group, trust, partnership or fund or an unincorporated association or organization. (entité)." ${ }^{50}$ Additionally, a "listed entity" is defined as "an entity on a list established by the Governor in Council under section 83.05. (entité inscrite)" ${ }^{\prime 51}$ The current list of some 53 entities is found on the Government of Canada, Public Safety Canada website. ${ }^{52}$ It is also relevant and important to point out that, even though it is not a crime to be a listed entity,

[i]t is an offence to knowingly participate in or contribute to, directly or indirectly, any activity of a terrorist group. This participation is only an offence if its purpose is to enhance the ability of any terrorist group to facilitate or carry out a terrorist activity. ${ }^{53}$

The legal definition of the crime of terrorism in Canada appears to be detailed and thorough and incorporates two main parts: terrorist activity and terrorist group. It also incorporates what is commonly understood to constitute terrorism, a politically motivated attack that is intended to incite fear in the society at large in order to influence the policymakers to a particular course of

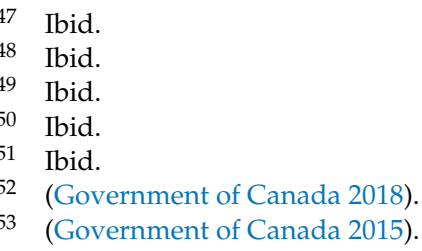


action. $^{54}$ The Canadian definition of the crime of terrorism incorporates international instruments directly in its definition and recognizes that terrorist acts can be conducted within Canada or abroad. It also recognizes that situations of armed conflict that involve the military of the State that is abiding by international law are excluded from the definition of terrorism. It is mindful of the fact that those who are complicit in terrorist activities and terrorist groups are criminally liable for their indirect participation in terrorism. Canada also maintains a list of "entities" that are involved in terrorist activities to help screen out all those who are involved in or support terrorist groups and/or organizations.

Ashley Carver has asserted that the motive clause in the Canadian definition of terrorism has "ratified racial profiling in Canadian law." 55 She goes on to state that

This means that violence motivated by any ideology, religion or political motivations that are proportionally outside "the mainstream" are at risk of being labeled as terrorist in nature. Consequently, it is clear that Canadian legislators have not overcome definitional challenges, but rather have resorted to labeling strategies that extend criminalization of violent attacks on mainstream politics, religion, or ideology beyond traditional criminal justice laws into the realm of antiterrorism. This failure is a direct result of the sociopolitical desire to legislate the label of terrorism into law without first overcoming its weaknesses. ${ }^{56}$

However, such concerns have not been realized in practice, as evident by various violent attacks that have occurred in Canada in the recent past. ${ }^{57}$

\subsection{Comparing and Contrasting the Three Definitions of the Crime of Terrorism in the UK, the US, and Canada}

\subsubsection{Similarities Amongst the Three States' Definitions of Terrorism}

All three States have extensive legislation on the crime of terrorism within their respective jurisdictions. In fact, the legislation has been in place for many years and has gone through multiple reviews and amendments. All three States have "listed entities" or lists of Foreign Terrorist Organizations or Proscribed Terrorist Organizations that are used to screen out all those who directly or indirectly support or are affiliated in some way with these proscribed terrorist organizations. These States seem to include a section that covers the offenses and the intention in their definition of terrorism. Canada and the United States have incorporated their definitions of terrorism directly within their respective criminal codes. Although, in the case of the US, criminal law is a concurrent jurisdiction and the fifty States have the authority to have their own definitions of terrorism. The UK has separate legislation that covers terrorism exclusively. ${ }^{58}$

All three jurisdictions recognize that terrorism constitutes the most violent and serious felonies or crimes possible that include death, serious bodily harm, serious risk to health, and the destruction of property and electronic systems, etc. They all recognize that terrorist activities are deliberately intended to affect and, therefore, influence to their overall end, not only the public or segments of the public through shock, fear, and anxiety over their security, but, more importantly, the policymakers and decision makers of the State. Canada and the United Kingdom recognize that there is an underlying motivation for terrorist actions that relates to the political, religious, racial, or ideological beliefs of the terrorists and their organizations. Race, however, is not an element that is incorporated in the Canadian

54 (Rana 2018) Wherein Justice John Norris provides a detailed judicial review of the definition of terrorism in the Canadian Criminal Code and the Supreme Court of Canada's 2002 Suresh judgement, and the definition of terrorism found there, as it relates to an inadmissibility case dealing with terrorism under section 34(1)(f) of the 2001 Immigration and Refugee Protection Act.

55 (Ca

56 Ibid.

57 (Bronskill 2018; Hamilton Spectator 2018; Roach 2018).

58 (Walker 2014). 
definition of terrorism. The US has refrained from attributing a motivation that drives terrorists to inflict such fear and trauma through seemingly senseless death and destruction on a society. Inferring motive without admission or reliable objective evidence in criminal proceedings is precarious at best, which may explain why the US criminal justice system has stayed clear of incorporating motive in its legislation defining terrorism.

Table 1 provides a summary of the key provisions of the law of terrorism in the UK, the US, and Canada. It immediately highlights that the US law of terrorism differs from the UK and Canada in terms of both its motive and locus. It also highlights the similarities across the three jurisdictions in terms of the means and intent.

Table 1. The Definition of Terrorism in the UK, the US, and Canada Compared.

\begin{tabular}{|c|c|c|c|c|}
\hline & MEANS & INTENT & MOTIVE & LOCUS \\
\hline $\begin{array}{c}\frac{\mathrm{UK}}{2000} \text { Terrorism } \\
\text { Act } \mathbf{1} \text { (1) }\end{array}$ & $\begin{array}{l}\text { "use or threat of action" } \\
\text { "that involves serious } \\
\text { violence, damage to } \\
\text { property or serious risk } \\
\text { to the health or safety of } \\
\text { the public, etc." }\end{array}$ & $\begin{array}{l}\text { "designed to influence the } \\
\text { government or international } \\
\text { governmental organization } \\
\text { or to intimidate the public or } \\
\text { section of the public" }\end{array}$ & $\begin{array}{l}\text { "advancing a } \\
\text { political, religious, } \\
\text { racial or ideological } \\
\text { cause" }\end{array}$ & $\begin{array}{l}\text { "includes } \\
\text { action outside } \\
\text { the United } \\
\text { Kingdom" }\end{array}$ \\
\hline $\begin{array}{c}\underline{\mathrm{US}} \\
\text { Title 18, US } \\
\text { Code, Part 1, } \\
\text { Chapter 113B }\end{array}$ & $\begin{array}{l}\text { "violent acts or acts } \\
\text { dangerous to human life } \\
\text { and are violations of the } \\
\text { criminal law of the US or } \\
\text { any State" }\end{array}$ & $\begin{array}{l}\text { "intimidate or coerce a } \\
\text { civilian population" } \\
\text { "influence the policy of a } \\
\text { government by intimidation } \\
\text { or coercion" } \\
\text { "affect the conduct of a } \\
\text { government by mass } \\
\text { destruction, assassination, or } \\
\text { kidnapping" }\end{array}$ & & $\begin{array}{l}\text { "international } \\
\text { terrorism" and } \\
\text { "domestic } \\
\text { terrorism" }\end{array}$ \\
\hline $\begin{array}{l}\text { Canada } \\
\text { CC Part II-I, } \\
\text { Terrorism, s. } \\
83.01 \text { (1) } \\
\text { "terrorist } \\
\text { activity" } \\
\text { "terrorist group" }\end{array}$ & $\begin{array}{l}\text { "act or omission"_-that } \\
\text { includes } 13 \text { functional } \\
\text { Conventions and } \\
\text { Protocols on Terrorism } \\
\text { "death or serious bodily } \\
\text { harm to a person by the } \\
\text { use of violence" } \\
\text { "causes substantial } \\
\text { property damage" }\end{array}$ & $\begin{array}{l}\text { "intimidating the public or a } \\
\text { segment of the public with } \\
\text { regard to security, including } \\
\text { economic security, or } \\
\text { compelling a person, } \\
\text { government or } \\
\text { organization" }\end{array}$ & $\begin{array}{l}\text { "committed in } \\
\text { whole or in part for } \\
\text { a political, religious } \\
\text { or ideological } \\
\text { purpose, objective } \\
\text { or cause" }\end{array}$ & $\begin{array}{l}\text { "in or outside } \\
\text { Canada" }\end{array}$ \\
\hline
\end{tabular}

\subsubsection{Differences Amongst the Three States' Definitions of Terrorism}

The Canadian definition of terrorism is in two parts: terrorist activity and terrorist group. The US definition of terrorism distinguishes between international terrorism and domestic terrorism. Additionally, the UK definition of terrorism does not include either the Canadian or the US division. Its focus is on the "use or threat of action" ${ }^{59}$ by the perpetrators of terrorism. In Canada, the focus is on "an act or omission that is committed in or outside Canada." ${ }^{100}$ In the United States, the focus of the definition of terrorism is on "violent acts or acts that are dangerous to human life that are a violation of the criminal laws of the United States or any State." 61

The US definition, as noted above, does not include a "motive clause" like those found in Canada and the UK. In Canada, the "act or omission, in or outside Canada, that is committed, (A) in whole or in part for a political, religious or ideological purpose, objective or cause" ${ }^{\prime 62}$ would constitute terrorism. In the UK, terrorism would be "the use or threat of action where ... (c) the use or threat is made for 
the purpose of advancing a political, religious [F2, racial] or ideological cause." ${ }^{\prime 63}$ The addition of race in the UK definition is an important distinction from the Canadian definition. Nonetheless, it could be argued that race could be subsumed under ideology. However, the mere fact that the UK has explicitly incorporated it in its definition is seemingly an important distinction from either Canada or the US.

The Canadian definition of terrorism is unique in that it directly incorporates most of the UN sectoral anti-terrorism conventions to define what constitutes terrorist activities. ${ }^{64}$

The US definition of terrorism is unique in outlining, under intention, both international and domestic terrorism "to affect the conduct of a government by mass destruction, assassination, or kidnapping. ${ }^{\prime 65}$

The UK includes, in section 3 of its definition, the provision that "The use or threat of action falling within subsection (2) which involves the use of firearms or explosives is terrorism whether or not subsection (1)(b) is satisfied." 66 When firearms and explosives are involved, then one does not need to show that there was any intent to influence or intimidate anyone.

Canada makes explicit reference to conspiracy, accessories after the fact, and counselling, and the definition of terrorism excludes activities committed in an armed conflict that are in accordance with customary and conventional international law or the activities of the military forces of a State in the exercise of their official duties that are consistent with international law. ${ }^{67}$ Such provisions are not found in either the US or the UK.

\subsection{Observations Emerging From the Comparative Analysis of the Definition of Terrorism Across These Three States}

A number of general observations emerge from this comparative analysis of how the UK, the US, and Canada each define terrorism. Firstly, Canada appears to have the most international definition that draws explicitly on the UN Conventions and Protocols that deal with specific acts of terrorism. Defining what constitutes a terrorist activity by drawing on these international instruments certainly internationalizes the Canadian Criminal Code definition of the crime of terrorism. This is further reinforced by the explicit exclusion of such activities during an armed conflict provided that they are consistent with the applicable international laws. There are no such references of these in either the UK or the US legislation.

The Canadian and UK definitions appear to be quite similar in a number of important respects, including the use of the "motive clause," the explicit reference to political, religious, racial, or ideological purposes, as a basis for the commission of terrorist activities. Where Canada and the UK differ, however, is that Canada uses the phrase, "acts or omissions", while the UK uses the phrase "use or threat of action." The phrase "acts or omissions" that are punishable by law is a common expression in criminal law. ${ }^{68}$ The UK phrase "use or threat of action" is broader than "acts or omissions" because it encompasses not only the action, but also the threat of the action. This may, in part, be compensated for by the use of inchoate crimes in the Canadian definition of terrorism. However, not entirely, which likely makes the UK definition of terrorism broader than the Canadian definition of terrorism.

The US definition, in contrast, merely refers to "activities," rather than either "acts or omissions" or "use or threat of action." Activities may not capture omissions, a non-activity, inadvertent or deliberate, but may incorporate the notion of the "threat of action," which can ostensively be interpreted to encompass threats to take an action(s). Thus, the US definition may lie closer to the UK definition and,

63 (legislation.gov.uk 2000).

64 Criminal Code (R.S.C, 1985, c. C-46), Part II-1-Terrorism, Section 83.01 (1)(a)(i) to (x).

65 (Cornell University Law School 2018a).

66 (legislation.gov.uk 2000). Section (1)(b) is "the use or threat is designed to influence the government [F1 or an international governmental organisation] or to intimidate the public or a section of the public."

67 (Justice Laws Website 2018), Part II-1-Terrorism, Section 83.01.

68 In criminal law, an omission will only incur liability, and constitute an actus reus, when the law imposes a duty to act and a person fails to do so. 
hence, be more expansive than the Canadian definition. However, as noted previously, the fact that the US may be incorporating the definition of terrorism of all other States within its definition, when it states "or of any State," would be certainly the most expansive definition among these three States.

The US definition of terrorism is quite distinctive, in many respects including the specific distinction between international and domestic terrorism and the reference to "mass destruction, assassination or kidnapping." As mentioned previously, the international and domestic distinction may be a feature of the US federal system and its concurrent jurisdiction in criminal law. The explicit references to mass destruction, assassination, or kidnapping are unique amongst the three States' definitions of the criminal offense of terrorism and may be related to the specific experiences of the United States with its numerous traumatic experiences, with both international and domestic terrorism in contrast to the UK or Canada.

In summation, the three definitions of terrorism in these three countries have some similarities with respect to means and intent, but are different from each other in important ways and, in particular, with respect to motive and locus. This legal analysis underscores that these definitions of terrorism are quite different in important respects. Accordingly, one could conclude that the definitions of terrorism in the UK, the US, and Canada are not the same. Whether this leads to a different fundamental understanding of what constitutes "terrorism" requires further analysis of the jurisprudence on the law of terrorism, which is the subject of the second part of this article that is presented immediately below.

\section{The Leading Jurisprudence on Terrorism in the United Kingdom, the United States, and Canada}

\subsection{Introduction}

This section of the article will analyze some of the recent leading jurisprudence on terrorism in the UK, the US, and Canada. It will do so by examining how the SCs in each of these jurisdictions have applied and interpreted the relevant statutes that define terrorism to discern how these final courts of appeal have addressed the constitutional issues involved in these leading terrorism cases. This section of the dissertation will examine how the respective SCs have dealt with some of the leading terrorism cases within each of their jurisdictions.

The cases for the jurisprudential analysis were selected on the basis that they dealt with some aspect of terrorism that was relevant to the definition of terrorism in the Criminal Codes and statutes in these jurisdictions. Seven current cases were selected for jurisprudential analysis for this study: two each from the UK and US and three from Canada. Three cases were selected for Canada because the Supreme of Canada provided a definition of terrorism in Suresh ${ }^{69}$, one of the Canadian cases analyzed below, that is still being applied in immigration and refugee law in Canada, in addition to the definition of terrorism found in the Canadian Criminal Code, which is the subject of the other two Canadian cases presented herein..$^{70}$ The cases do not purport to be representative of all of the cases that have dealt with terrorism or some aspects of terrorism within these jurisdictions. The respective SCs select the cases that are granted leave to appeal with great care and only if the case deals with important constitutional issues that need to be resolved. In that sense, then, each of the cases that are accepted for judicial review by each of these SCs is quite different and unique. The cases differ on the facts, the legal issues, and the constitutional questions that need to be resolved and/or decided. Accordingly, there is no pretense that these cases are representative samples of the terrorism cases that appear before the SCs in each of these jurisdictions or across these three jurisdictions. Nonetheless, a jurisprudential analysis of these seven cases should allow for some meaningful conclusions with respect to the manner in which the law of terrorism is applied and interpreted in these three States and most importantly, whether the jurisprudential trend is towards convergence or divergence on the law of terrorism. A divergence in

69 Suresh v. Canada (Minister of Citizenship and Immigration), [2002] 1 S.C.R. 3, 2002 SCC 1.

70 See footnote 54 above and, in addition, Intisar v. Minister of Citizenship and Immigration Canada, (F. C. no. IMM-1627-18), Southcott, November 8, 2018, FC 1128, paragraph 12, page 6. 
jurisprudential trends with respect to the definition of what constitutes terrorism, as noted previously, would not auger well for robust and effective counter-terrorism strategies and policies across these three jurisdictions. In an ever globalized environment, with the attendant emergence of the threat of international terrorism, the necessity for consistent and collaborative legal effort becomes ever more evident.

\subsection{The Leading UK Jurisprudence on Terrorism}

The two cases selected from the UKSC are $R v$ Gul and Beghal $v$ Director of Public Prosecutions. The first case dealt directly with the definition of terrorism in the Terrorism Act 2000 and the second case dealt with Schedule 7 of the Terrorism Act that gives immigration and border officials the right to stop and question a person at the border and ports of entry who they suspect may be involved in terrorism. In both cases, the UKSC upheld the legislation as constitutional and not in breach of the European Convention of Human Rights (ECHR).

\subsubsection{R v Gul}

In $R v G u l^{71}$, the UK Supreme Court addressed the issue of the meaning of "terrorism" in section 1 of the UK Terrorism Act 2000. The case involved a British national who was born in Libya. In 2009, the police exercised a search warrant on his home and found videos on his computer that depicted attacks by Al-Qaeda and the Taliban and other proscribed groups on military targets in Chechnya and on Coalition Forces in Iraq and Afghanistan; the use of improvised explosive devices (IEDs) against Coalition Forces; excerpts from "martyrdom videos"; and clips of attacks on civilians, including the 9/11 attacks on New York City. The appellant was charged, prosecuted, and convicted on five of six counts for committing an offence under section 2(1) of the Terrorism Act of 2006 for distributing or circulating "a terrorist publication." 72 He was then sentenced to five years, with appropriate time spent in remand. ${ }^{73}$

On appeal, the Court of Appeal certified the following question of general public importance:

Does the definition of terrorism in section 1 of the Terrorism Act 2000 operate so as to include within its scope any or all military attacks by a non-state armed group against any or all state or intergovernmental organisation armed forces in the context of a non-international armed conflict? ${ }^{74}$

The Court of Appeal answered the certified question in the affirmative, rejected all other grounds to appeal, and upheld the judge's sentence. The appellant's appeal to the UKSC was based on the argument that its answer to the certified question should be in the negative. ${ }^{75}$

The UK Supreme Court duly acknowledged the Court of Appeal's judgement that the definition of terrorism, in the 2000 Terrorism Act, is "comprehensive" in scope and "broad" in nature. ${ }^{76}$ Under the Act, the definition of terrorism can be broken down into three strands: the first is the "use or threat of action," inside or outside the UK, where that threat to action consists of "serious violence," "serious property damage" or creating a serious risk to public safety or health. ${ }^{77}$ The use or threat of violence must be designed "to influence government (the UK or any other country), or an international

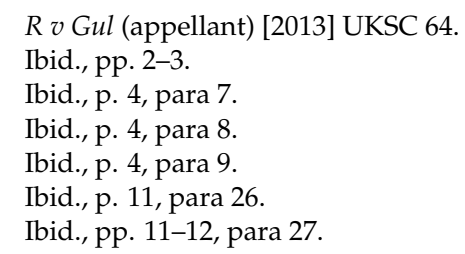


governmental organization (IGO) or to intimidate the public." ${ }^{\prime 78}$ Furthermore, the use or threat of action is "made for the purposes of advancing a political, religious, racial or ideological cause,"79

The Court made the point that "the definition of terrorism in section 1 in the 2000 Act is, at least when read in its natural sense, very far reaching indeed." ${ }^{80}$ However, this is tempered by the fact that section 117 calls for any prosecution under the 2000 Terrorism Act to require the consent of the Director of Public Prosecutions (DPP), or, if the activities under consideration occurred abroad, then the consent of the Attorney General. ${ }^{81}$

The appellant contended "terrorism" ought to be given a meaning in statutes that accords with international norms and with the definition that is found in the relevant international instruments. It was further argued that the 2000 and the 2006 Acts criminalize certain "terrorist" actions that are committed outside the UK; accordingly, the meaning of "terrorism" in those statutes should not be wider than is accepted by international norms. ${ }^{82}$

The UK Supreme Court noted that the common obstacle that both of the appellants' arguments face is that there are no accepted international law norms as to what constitutes terrorism. The Court cited its judgement in Al-Sirri v. Secretary of State for the Home Department (United Nations High Commissioner for Refugees intervening) [2013] 1 AC 745, para 37, "'there is as yet no internationally agreed definition of terrorism' and 'no comprehensive international Convention binding Member States to take action against it'.",83

The UK Supreme Court pointed out that in its Al-Sirri judgement, an attack on the International Security Assistance Force in Afghanistan could be seen as an act contrary to the purposes and principles of the United Nations and that such an attack, therefore, could constitute an act of terrorism. ${ }^{84}$ Further, there have been UN resolutions referring to the activities of al-Qaida and the Taliban as "terrorism," notwithstanding allegations that their acts involved insurgents attacking states and IGOs in non-international armed conflicts. ${ }^{85}$

The UK Supreme Court came to the decision that the answer to the certified question was "yes," and, consequently, the appeal was dismissed.

Antonio Coco has noted that the UKSC, in $R v$. Gul, found "the terrorism definition in UK law to be both unwise and undesirable but then relied on it to confirm the defendant's conviction." ${ }^{86}$ Coco goes on to observe that

The definition is practically very broad ... It seems to label as terrorist most acts of warfare in a NIAC, regardless of whether they are lawful or unlawful under International Humanitarian Law (IHL) and whether they are carried out by the armed forces of a State or by a non-State armed group. Indeed, most hostile acts in an armed conflict are likely to cause serious violence to persons or serious damage to property, and all of them are motivated by a political or ideological cause. Arguably, any hostile act in an armed conflict is designed to influence a government or involves the use of firearms or explosives. According to this definition, every person embracing weapons in a NIAC is considered a terrorist.

... Arguably, a definition of terrorist attacks in war-time-as 'acts or threats of violence the primary purpose of which is to spread terror among the civilian population'-is envisaged by art. 51(2) of Additional Protocol I (AP I) to the Geneva Conventions and art. 13(2) of Additional

\footnotetext{
Ibid., p. 12, para 27.

Ibid.

Ibid., p. 12, para 29.

Ibid., p. 12, para 30

Ibid., p. 16, para 43

Ibid., p. 16, para 44

Ibid., p. 18, para 49

Ibid., p. 18, para 49

86 (Coco 2013).
} 
Protocol II (AP II), both deemed to have reached customary status (See the ICRC Study on customary IHL, Rule 2). ${ }^{87}$

In essence, Coco appears to argue that the UKSC has acquiesced to the UK government's broad definition of terrorism under its counterterrorism laws.

Alan Greene's case note on $R v G u l$ takes a more sanguine view of the judgement, which he argues provides, in its powerful obiter dictum, a refined definition of terrorism "without hampering the apparent 'operational necessity' for a broad malleable definition." 88

\subsubsection{Beghal v Director of Public Prosecutions}

Sylvie Beghal was married to Djamel Beghal, who was being prosecuted on terrorism charges in France, at the time this case was being decided at the UK Supreme Court. ${ }^{89}$ Mrs. Beghal was returning from Paris, France, with her three children after visiting her husband, and while passing through East Midlands Airport on January 4, 2011, she was stopped and questioned by the authorities under Schedule 7 of the Terrorism Act 2000. Persons who are stopped for questioning under the Act are required to answer questions put to them by police officers, immigration officers, and customs officers. ${ }^{90}$ Mrs. Beghal was questioned by the authorities for less than half an hour and she refused to answer most of the questions put to her. ${ }^{91}$ She was charged with the offense under the Act of willful failure to comply with the requirement to answer questions. ${ }^{92}$ Following an unsuccessful application of stay of proceedings before a District Judge, on the grounds of an abuse of process, she pleaded guilty and was sentenced to a conditional discharge. ${ }^{93}$ Nonetheless, she appealed her conviction on the grounds that Schedule 7 of the Terrorism Act 2000 was contrary to the ECHR, especially, Article 8 (right to respect for family and private life), Article 5 (right to liberty), and Article 6 (privilege against self-incrimination).

The majority judgement of the Court begins with the relevant statutory provisions of the 2000 Terrorism Act:

4. The statutory purpose for which the questions may be asked is thus for determining whether the person questioned appears to fall within section 40(1)(b). That in turn defines "terrorist" for the purposes of the Act, and does so in these terms:

(1) In this Part 'terrorist' means a person who-

(a) has committed an offence under any of sections $11,12,15$ to 18,54 and 56 to 63 , or

(b) is or has been concerned in the commission, preparation or instigation of acts of terrorism.

5. "Terrorism" is defined for the purposes of the Act in section 1 . Shorn of inessential detail it means the use or threat of action which meets all of three conditions: (1) it must be done for the purpose of advancing a political, religious, racial or ideological cause, (2) it must be designed to influence the government or an international governmental organisation or to intimidate the public and (3) it must involve serious violence to a person or to property, danger to life or serious risk to public health or the risk of serous interference with an

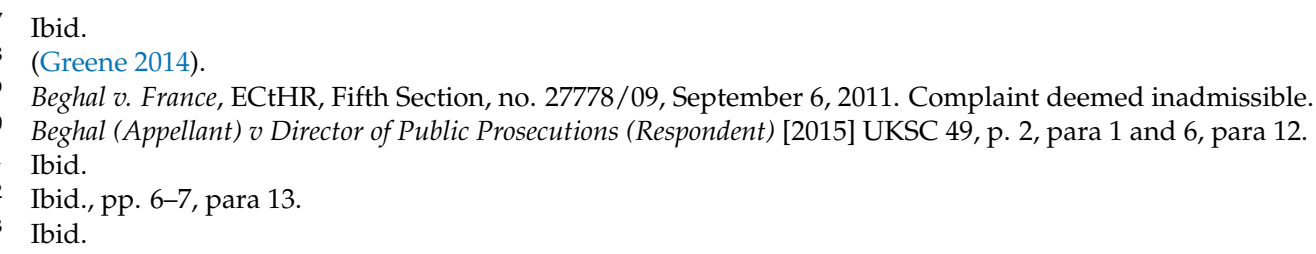


electronic system. "Acts of terrorism" are therefore to be construed as acts or omissions having these characteristics. ${ }^{94}$

The Court goes on to remark that Schedule 7 of the Terrorism Act 2000 creates the power for the authorities to stop and question people who are passing through ports and borders to detect terrorists or those who "have been concerned in the commission, preparation or instigation of acts of terrorism." ${ }^{\prime 95}$ If the person willfully fails to comply with the obligations of Schedule 7, then they may be subject to conviction of an offense that could result in a fine and/or an imprisonment of up to three months. ${ }^{96}$

“(1) A person commits an offence if he-

(a) willfully fails to comply with a duty imposed under or by virtue of this Schedule;

(b) willfully contravenes a prohibition imposed under or by virtue of this Schedule; or

(c) willfully obstructs, or seeks to frustrate, a search or examination under or by virtue of this Schedule." ${ }^{\prime 97}$

It is important and relevant to note two things. The first is that there is a Code of Practice that is available publicly, for all those who exercise authority under Schedule 7 of the 2000 Terrorism Act. ${ }^{98}$ Additionally, the second is that the officers' power of questioning under Schedule 7 is separate from the general power to arrest, detain, and question persons who are reasonably expected of having committed an offense, and, in the context of terrorism, from the specific power to arrest on reasonable suspicion of having been concerned in the commission, preparation, or instigation of an act of terrorism. ${ }^{99}$

The test for determining whether Schedule 7 interferes with Articles 8, 5, and 6 of the ECHR is whether it is: (1) in accordance with the law; and, (2) a proportionate means to a legitimate end. ${ }^{100}$ On the question of legality, the Court notes that "there must be a lawful domestic basis for it, that this law must be adequately accessible to the public and that its operation must be sufficiently foreseeable, so that people who are subject to it can regulate their conduct."101 However, the law must go beyond this "to contain sufficient safeguards to avoid the risk that power will be arbitrarily exercised and thus that unjustified interference with a fundamental right will occur." 102 The Court positively cites Lord Reed in the $R(T)$ judgement, who noted that to satisfy the test of "legality there must be sufficient safeguards in place to demonstrate that the State has properly addressed the issue of proportionality of any interference and enabled it to be examined in a particular instance." ${ }^{103}$ Nevertheless, legality is distinct from proportionality and is a prior test which is designed to ensure that interference with a Convention right is proportional. ${ }^{104}$

The Court concluded that there are sufficient effective safeguards in the manner of operation to meet the requirements of legality. ${ }^{105}$ A list of ten of these safeguards is provided by way of illustration. ${ }^{106}$ It asserts that the principle of legality is satisfied for Schedule 7 port questioning power and that the "need for safeguards by the quality of intrusion into individual liberty and the risk of

\footnotetext{
94 Ibid., p. 3, para 4-5.

95 Ibid., p. 4, para 7.

96 Ibid., p. 5, para 9.

97 Ibid.

98 Ibid., p. 5, para 10.

99 Ibid., pp. 5-6, para 11.

100 Ibid., pp. 12-13, para 28.

101 Ibid, p.13, para 29.

102 Ibid., para 30.

103 Ibid., p. 14, para 31

104 Ibid., para 33.

105 Ibid., p. 18, para 43

106 Ibid., p. 19, para 43.
} 
arbitrary misuse of the power." 107 It observes that there are sufficient safeguards against the use of arbitrary power and there are effective controls via judicial review and the Independent Reviewer to provide a corrective if it should occur. ${ }^{108}$

With regard to proportionality, the Court relies on Lord Sumption's formulation of proportionality in four questions, as found in Bank Mellat v HM Treasury (No 2) [2013] UKSC 39; [2014] AC 700, 770-771, para $20 .{ }^{109}$ The four questions are as follows:

(i) is the objective sufficiently important to justify limitation upon a fundamental right?

(ii) is the measure rationally connected to the objective?

(iii) could a less intrusive measure have been adopted? and,

(iv) has a fair balance been struck between individual rights and the interests of the community? ${ }^{110}$

As to question one above, the Court stated that the objective of Schedule 7 "is clearly not border control per se but rather the prevention and detection of terrorism." ${ }^{111}$ It is plainly evident, the Court observes, that the power of questioning and search is rationally connected to the objective. With respect to questions (iii) and (iv) above, the Court notes that there is a plain rational reason for connecting questioning and search that is aimed at the prevention and detection of terrorism with border controls. ${ }^{112}$

The Court also stresses the value of the questioning and search power at the port of entry/exit to be a valuable intelligence gathering tool that would be lost with a system based on suspicion on reasonable grounds. ${ }^{113}$ It therefore finds that the port questioning and search powers represent a fair balance between the rights of the individual and the interests of the community at large and do not breach Article 8 of the ECHR. ${ }^{114}$

On the question of whether a breach of Article 5 of the ECHR had taken place due to the appellant's detention, the Court ruled that her deprivation of liberty was for no longer than necessary for the completion of the process and there was no requirement for her to attend a police station. Consequently, there was no breach of Article 5. ${ }^{115}$

In Sean O'Bierne's case comment on Beghal v. DPP, he notes that David Anderson, QC, the Independent Reviewer for the Terrorism Legislation in the UK, raised the following concerns regarding Schedule 7 of the Terrorism Act 2000:

1. the fact that no suspicion is required for the exercise of most Schedule 7 powers;

2. the fact that answers given under compulsion are not expressly rendered inadmissible in criminal proceedings; and

3. the need for clear and proportionate rules governing the data taken from electronic devices. ${ }^{116}$

At present, there are no provisions planned to address these particular concerns regarding the application of Schedule 7.

The case has gone to the European Court of Human Rights, where the applicant claims that the exercise of Schedule 7 powers breached her rights under Articles 5, 6, and 8 of the ECHR. ${ }^{117}$

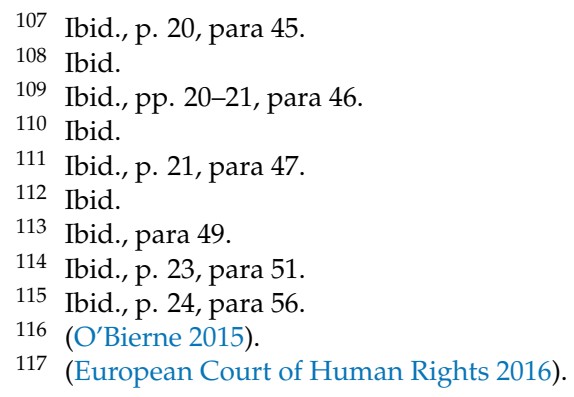




\subsection{Some US Jurisprudence on Terrorism}

The two cases selected from the US Supreme Court are Hamdan v. Rumsfeld and the Holder $v$. Humanitarian Law Project. In Hamdan v. Rumsfeld, the accused was charged with "conspiracy." USSC found, in a five to three judgement, that there was no such charge under International Humanitarian Law and it went on to strike down the legality of the Military Commissions that were established by the Bush Administration to try the detainees that were held at Guantanamo Bay, the so-called "enemy combatants." The USSC ruled that the Military Commission violated the detained suspects' rights under the Geneva Conventions and the US Code of Military Justice. This was, undoubtedly, one of the most important judgements ever rendered by the USSC based virtually entirely under international law. ${ }^{118}$ In the Holder v. Humanitarian Law Project, the USSC ruled that the material support bar against terrorism did not violate the US Bill of Rights.

\subsubsection{Hamdan v. Rumsfeld}

This case involved a Yemeni national, Salim Ahmed Hamdan, who was held in the US prison at Guantanamo Bay, Cuba. He was captured initially by militia forces in Afghanistan in November 2001 and turned over to the US military and in June 2002, he was transferred to Guantanamo Bay. ${ }^{119}$ He was deemed eligible to be tried on unspecified charges by military commission by the US President over a year later. ${ }^{120}$ Another year passed before he was eventually charged with "one count of conspiracy 'to commit ... offenses triable by military commission. "'121

Hamdan filed writs of habeas corpus and mandamus challenging the legal authority of the military commissions and the charges filed against him. ${ }^{122}$ He argued that the military commissions lack authority to try him for two principal reasons: (1) "neither the Congressional Act nor the common laws of war supports trial by this military commission for the crime of conspiracy," 123 which Hamdan argued, is not a violation of the laws of war; and, (2) "the procedures that the President has adopted to try him violate the most basic tenets of military and international law,"124 including the fundamental legal principle that the defendant is entitled to see and to hear the evidence against him. ${ }^{125}$

The background and context for this case are critical. The September 11, 2001, terrorist attacks on the US mainland, the worst terrorist attacks in modern history, were precipitated by agents of al-Qaeda. The US Supreme Court notes that, "Americans will never forget the devastation wrought by these attacks." 126 The response of the US Government was swift and thorough. Congress passed a Joint Resolution calling on the President to "'use all necessary and appropriate force against those nations, organizations or persons he determines planned, authorized, committed or aided the terrorist attacks ... in order to prevent any future acts of terrorism against the United States by such nations, organizations or persons." "127 After determining that the Taliban regime in Afghanistan supported al-Qaeda, the President ordered the Armed Forces of the United States to invade Afghanistan. ${ }^{128}$ Hamdan was one of hundreds of individuals who were captured and eventually detained at Guantanamo Bay.

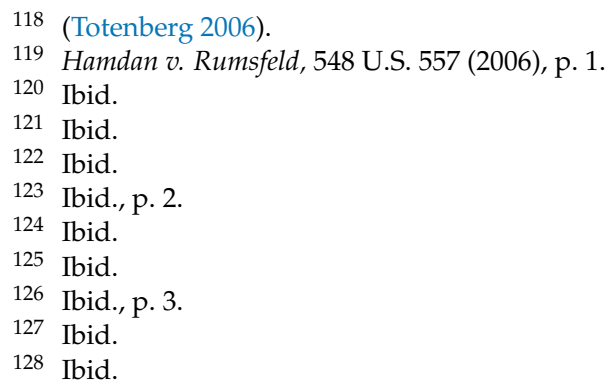


The USSC points out that none of the alleged acts that Hamdan was charged with took place on any specific date after September 2001 or in a Theatre of War. ${ }^{129}$ Nor did any of the acts that he was alleged to have committed violate the laws of war. ${ }^{130}$ All of this clearly casts doubt on the legality of the charges laid and, indeed, the military commissions. ${ }^{131}$ However, the most serious defect in the charges laid, the Court notes, is the alleged offence is not triable by a law-of-war military commission. ${ }^{132}$ Congress has not identified "conspiracy" as a war crime. This crime does not appear, the Court states, in either the Geneva Conventions or the Hague Conventions. ${ }^{133}$

The Court ruled that the military commission lacks the authority to try Hamdan. It further noted that the procedures that were adopted to try Hamdan are not consistent with those governing court-martial and their deviation is not justified through any evidence of practical necessity and, therefore, fail to afford the requisite guarantees. ${ }^{134}$ Moreover, the Court notes that provisions of the military commission dispense with the principles in Article 75 of Protocol I of 1977 of the Geneva Conventions of 1949 and that are part of customary international law and stipulate that an accused must be, absent of disruptive behavior, present for their trial and to hear the evidence against him $/$ her. ${ }^{135}$

In essence, the Court ruled that the military commission convened to try Hamdan does not conform to the requirements of Common Article 3 of the Geneva Conventions of $1949 .{ }^{136}$ Ultimately, the Supreme Court simply stated that "the Executive is bound to comply with the Rule of Law that prevails in this jurisdiction." ${ }^{\prime 37}$

\subsubsection{Holder v. Humanitarian Law Project}

In the Holder v. Humanitarian Law Project, ${ }^{138}$ the United States Supreme Court, in a six to three majority judgement delivered by Chief Justice John Roberts, decided on the constitutional validity of the 18 U. S. C. $\$ 2339 \mathrm{~B}$, which makes it a federal crime to "knowingly provid[e] material support or resources to a foreign terrorist organization." 139 The justification for the prohibition on the provision of "material support or resources" to specified foreign terrorist organizations is that they "are so tainted by their criminal conduct that any contribution to such an organization facilitates that conduct."140 The plaintiffs in this matter argued that the statute was too vague and violated the Fifth Amendment, the right to due process, the double jeopardy prohibition, and not having to testify against one's self, etc., and that it also violated the First Amendment in relation to freedom of speech and association. ${ }^{141}$

In 1997, the US Secretary of State designated the Kurdistan Workers' Party, the Partiya Karkeran Kurdistan or PKK, the Liberation Tigers of Tamil Eelam (LTTE), and 28 other organizations, as foreign terrorist organizations. ${ }^{142}$ The plaintiffs filed a law suit in federal court in 1998 challenging the constitutionality of the material-support statute, $\$ 2339 \mathrm{~B}$, on the grounds that they wanted "to provide support for the humanitarian and political activities of the PKK and the LTTE in the form of monetary

\footnotetext{
129 Ibid., p. 36.

130 Ibid.

131 Ibid

132 Ibid

133 Ibid., p. 40.

134 Ibid., p. 71.

135 Ibid.

136 Ibid., p. 72.

137 Ibid. Clearly, one of the most direct and biting critiques ever levelled against the Executive branch of the US government by the USSC.

138 Holder v. Humanitarian Law Project, 561 U.S. 1 (2010), 130 S.Ct. 2705.

13918 U. S. C. $\$ 2339 B(a)(1)$. The terms "terrorist activity" and "terrorism" are defined in 8 U. S. C. \$1182(a)(3)(B)(iii), and 22 U. S. C. $\$ 2656 \mathrm{f}(\mathrm{d})(2)$. [All in text citations and references are omitted.]

140 Holder v. Humanitarian Law Project, 561 U.S. 1 (2010), 130 S.Ct. 2705., p. 1. Wherein reference is made to the 1996 Antiterrorism and Effective Death Penalty Act (ADPA), §301(a)(7), §110 Stat. 1247, note following 18 U.S.C. 2339B (Findings and Purpose).

141 Ibid., p. 2.

142 Ibid., p. 3.
} 
contributions, other tangible aid, legal training, and political advocacy,"143 but they were prohibited from doing so for fear of prosecution under §2339B. The plaintiffs claimed that the statute was unconstitutional because it violated their rights under the First Amendment, freedom of speech, and freedom of association, by criminalizing their material provision of support to the PKK and LTTE without requiring the Government to prove that the plaintiffs had a specific intent to further the unlawful ends of these organizations. ${ }^{144}$ The plaintiffs also argued that the statute was too vague and, hence, unconstitutional. ${ }^{145}$

Ultimately, on the question of material support, the Supreme Court states that it is meant to "promot[e] peaceable, lawful conduct ... can [in fact] further terrorism by foreign groups in multiple ways." 146 The point was made that such "support frees up other resources within the organization that may be put to violent ends." 147 It can also add legitimacy to foreign terrorist groups that "makes it easier for those groups to persist, to recruit members, and to raise funds-all of which facilitate more terrorist attacks." ${ }^{148}$ Further, the evidence presented indicates that "terrorist groups systematically conceal their activities behind charitable, social, and political fronts." ${ }^{\prime 49}$ Moreover, there is evidence that indicates that the PKK and the LTTE, especially, have not respected the line between humanitarian and violent activities. ${ }^{150}$

The US Supreme Court also considered the foreign policy implications and the international counter-terrorism efforts of the material-support statute and stated that providing foreign terrorist groups with material support in any form also furthers terrorism by straining the United States' relationships with its allies and undermining cooperative efforts between nations to prevent terrorist attacks. ${ }^{151}$

It goes on to cite a US State Department report that states, "' $[\mathrm{t}]$ he experience and analysis of US government agencies charged with combating terrorism strongly suppor[t]' Congress's finding that all contributions to foreign terrorist organizations further their terrorism." ${ }^{152}$ Specifically, with respect to the kind of support that the plaintiffs wish to provide the PKK and LTTE, training to use humanitarian and international law to resolve disputes peacefully; to instruct PKK members how to petition various representative bodies such as the United Nations for relief; and to engage in political advocacy on behalf of Kurds in Turkey and Tamils in Sri Lanka. ${ }^{153}$ The Supreme Court ruled that "prohibiting the particular forms of support that plaintiffs seek to provide to foreign terrorist groups, §2339B, does not violate the freedom of speech." ${ }^{154}$

\subsubsection{Commentaries on Hamdan and the Humanitarian Law Project}

With respect to the Hamdan v. Rumsfeld judgement, Glenn Greenwald has argued that the USSC ruled that in the absence of an emergency, the US Constitution requires that the President must comply with Congressional law, even in areas of national security. ${ }^{155}$ To underscore the point, he quotes Justice Breyer's opinion that

Congress has denied the President the legislative authority to create military commissions of the kind at issue here.... Where, as here, no emergency prevents consultation with

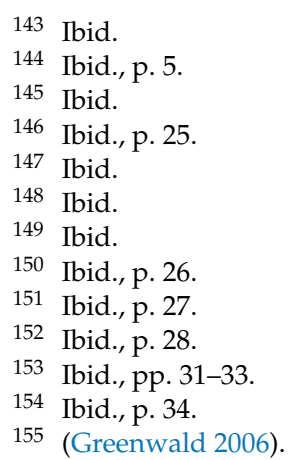


Congress, judicial insistence upon that consultation does not weaken our Nation's ability to deal with danger. To the contrary, that insistence strengthens the Nation's ability to determine-through democratic means-how best to do so. The Constitution places its faith in those democratic means. Our Court today simply does the same. ${ }^{156}$

The US National Constitution Centre came to the conclusion that in the Hamdan $v$. Rumsfeld judgement,

Beyond stirring controversy around issues of executive action and the treatment of suspected terrorists, these cases [including Rasul v. Bush (2004), Bush v. Boumediene (2008)], raise integral questions about just how far the reach of constitutional protection should extend. Even more pertinently, they highlight the unavoidable and constantly developing conflict between the preservation of national security and the guarantee of constitutional rights-a conflict that will likely never cease. ${ }^{157}$

The Holder v. Humanitarian Law Project judgement was the first ever challenge of the US Patriot Act at the USSC that examined the "overbroad scope of the prohibition of 'material support' to listed terrorist organizations, which effectively criminalized peacebuilding programs of US organizations in conflict zones around the world." 158 David D. Cole, who was the lawyer for the plaintiffs with the Center of Constitutional Rights, stated that "This decision basically says that the First Amendment allows making peacemaking and human rights advocacy a crime."159

Thus, the Hamdan $v$. Rumsfeld USSC judgement was celebrated as a major victory for the protection of the rule of law and the constitutional protection of fundamental human rights of those accused of serious crimes in times of armed conflict, while the Holder v. Humanitarian Law Project was roundly criticized for limiting the freedom of speech and criminalizing constructive peacemaking efforts and human rights advocacy.

\subsection{The Leading Canadian Jurisprudence on Terrorism}

The three judgements selected from the SCC were Suresh, Application under s. 83.28 of the Criminal Code, and Khawaja. In Suresh, the SCC found that the relevant sections of the Immigration Act did not violate the Canadian Charter of Rights and Freedoms and the terms "danger to the security of Canada" and "terrorism" were not constitutionally vague. In Application under s. 83.28 of the Criminal Code, the SCC determined that the Investigative Hearing was constitutionally valid and that it did not infringe on the independence and impartiality of the judiciary. In the important SCC judgement in Khawaja, it not only upheld the definition of terrorism in the Canadian Criminal Code as not being constitutionally vague or overly broad, but also found that it did not infringe on Sections 7 and 2 of the Canadian Charter of Rights and Freedoms. In all three of these high profile terrorism cases, the SCC upheld and endorsed the Canadian government's anti-terrorism legislation and policies.

\subsubsection{Suresh v. Canada (Minister of Citizenship and Immigration)}

Manickavasagam Suresh, a Sri Lankan Tamil, arrived in Canada in 1990 and was recognized as a Convention refugee in 1991. ${ }^{160}$ In 1995, he was detained by the authorities on the grounds that he was a fundraiser and member of the Liberation Tigers of Tamil Eelam (LTTE), an organization known to be engaged in terrorist activities. The government started proceedings to deport him and he challenged the order for his deportation on various grounds of substance and procedure.

The Supreme Court of Canada laid out the issues in the following manner:

\footnotetext{
156 Ibid., Emphasis added to the original judgement.

157 (National Constitution Centre 2017).

158 (Charity and Security Network 2010).

159 (Liptak 2010).

160 Suresh v. Canada (Minister of Citizenship and Immigration), [2002] 1 S.C.R. 3, 2002 SCC 1, para 1.
} 
On the one hand stands the manifest evil of terrorism and the random and arbitrary taking of innocent lives, rippling out in an ever-widening spiral of loss and fear. Governments, expressing the will of the governed, need the legal tools to effectively meet this challenge.

On the other hand stands the need to ensure that those legal tools do not undermine values that are fundamental to our democratic society-liberty, the rule of law, and the principles of fundamental justice-values that lie at the heart of the Canadian constitutional order and the international instruments that Canada has signed. In the end, it would be a Pyrrhic victory if terrorism were defeated at the cost of sacrificing our commitment to those values. Parliament's challenge is to draft laws that effectively combat terrorism and conform to the requirements of our Constitution and our international commitments. ${ }^{161}$

The Solicitor General and the Minister of Citizenship and Immigration filed a certificate under section 40.1 of the Immigration Act alleging that Suresh was inadmissible to Canada on security grounds. ${ }^{162}$ The section 40.1 certificate was based on the opinion of the Canadian Security Intelligence Service (CSIS) that Suresh is a member of the LTTE that is engaged in terrorist activity in Sri Lanka, and operates in Canada under the auspices of the "World Tamil Movement" (WTM). ${ }^{163}$

On September 17, 1997, the Minister notified Suresh that she was considering issuing an opinion that would declare him a danger to Canada under section 53(1)(b) of the Act. This section allows the Minister to deport a refugee on security grounds, even where a refugee's "life or freedom" would be threaten upon return. ${ }^{164}$ On January 6, 1998, the Minister issued an opinion that Suresh constituted a danger to the security of Canada and should be deported pursuant to section 53(1)(b). He was not given a copy of the Immigration Officer's, Citizenship and Immigration Canada, memorandum, nor was he given an opportunity to respond either orally or in writing. ${ }^{165}$ No reasons for the opinion were required under section 53(1)(b) and none were provided. ${ }^{166}$

Suresh appealed the Minister's danger opinion to the Federal Court, arguing that it was unreasonable and unfair because the procedures under the Act did not require an oral hearing before an independent decision-maker. Moreover, the Act was unconstitutional because it violated sections 7 and 2 of the Charter. ${ }^{167}$ The Federal Court denied the appeal on all grounds. Suresh then appealed to the Federal Court of Appeal and his application was again dismissed.

The threshold question before the SCC in Suresh was whether there was a substantial risk of torture if he was deported to Sri Lanka. ${ }^{168}$ The Court notes that this is a "fact-driven question." 169 This requires the consideration of a number of factors, including: the human rights record of the home state; the personal risk faced by the claimant; any assurances that the home state gives that they will not torture the claimant and their worth; the ability of the home state to control its own security forces; and more. ${ }^{170}$ The Court opines that the Minister's opinion as to whether Suresh faces a substantial risk of torture attracts deference by the reviewing Court. ${ }^{171}$ The reviewing Court cannot reweigh the factors considered by the Minister, but may intervene if the evidence does not support the opinion or fails to consider the appropriate factors. ${ }^{172}$

\footnotetext{
161 Ibid., paras 3-4

162 Ibid., para 9.

163 Ibid., para 10.

164 Ibid., para 15.

165 Ibid., para 16.

166 Ibid.

167 Ibid., para 17.

168 Ibid., para 39.

169 Ibid.

170 Ibid.

171 Ibid.

172 Ibid.
} 
The central issue before the Supreme Court of Canada in Suresh was does the Immigration Act permit deportation to torture contrary to the Charter? Section 53 of the Act does permit deportation to a country where a person's life and freedom may be threatened. ${ }^{173}$ The critical question is whether it violates section 7 of the Charter on rights to life, liberty, and security and, if so, whether it is in accordance with the principles of fundamental justice. ${ }^{174}$ If it is not in accordance with the principles of fundamental justice, then section 7 of the Charter is violated and, barring any justification under section 1 of the Charter, then deportation to torture is unconstitutional. ${ }^{175}$

The principles of fundamental justice are determined by a contextual approach that takes into consideration the nature of the decision to be made. ${ }^{176} \mathrm{It}$ is, essentially, a matter of balancing and as the Court stated in United States v. Burns, [2001] 1 S.C.R. 283, 2001 SCC 7, it is inherent in the "balancing process that the outcome may well vary from case to case depending on the mix of contextual factors put in the balance." 177 Deportation to torture requires a careful consideration of a wide set of factors and the resulting balance struck will be dependent, at least in part, on the personal situation and circumstances of the potential deportee; the general circumstances, including the danger the potential deportee poses to Canadians and the security of Canada; and the threat of terrorism in Canada. ${ }^{178}$ The balance struck will vary from case to case.

As to the international perspective, the Court states, "A complete understanding of the Act and the Charter requires consideration of the international perspective." ${ }^{\prime 179}$ However, the Court also acknowledges that treaty norms are not binding in Canada unless they have been incorporated in Canadian legislation. The Court, however, looks to international law not to discern Canada's binding legal obligations but, rather, to discern the principles of fundamental justice. ${ }^{180}$ After a thorough review of the relevant international instruments, the Court concluded that "international law rejects deportation to torture, even when national security interests are at stake." 181 Hence, "barring extraordinary circumstances, deportation to torture will generally violate the principles of fundamental justice protected by section 7 of the Charter."182

The central concern, according to the Court, is not the legislation, section 53(1)(b), that permits deportation to torture, and which the Court ruled was not in violation of section 7 of the Charter, but the Minister's obligation to exercise the discretion of section 53(1)(b) in a constitutional manner. ${ }^{183}$

Suresh asserted that "danger to the security of Canada" was unconstitutional because it was vague. The Court ruled that "danger to the security of Canada" is not constitutionally vague and that a fair, large, and liberal interpretation in accordance with international norms be accorded to "danger to the security of Canada" in deportation legislation. ${ }^{184}$ However, returning a refugee to torture under section 53(1)(b) of the Act, the Court noted, requires evidence of a serious threat to national security: "To suggest that something less than serious threats founded on evidence would suffice to deport a refugee to torture would be to condone unconstitutional application of the Immigration Act." 185 The Court states that the threat must be "serious" in the sense that it should be grounded in "objectively

173 Ibid., para 43.

174 Ibid.

175 Ibid., para 44.

176 Ibid., para 45.

177 Ibid.

178 Ibid.

179 Ibid., para 59.

180 Ibid., para 60.

181 Ibid., para 75.

182 Ibid., para 76.

183 Ibid., para 79

184 Ibid., para 85.

185 Ibid., para 89. 
reasonable suspicion based on evidence and in the sense that the threatened harm must be substantial rather than negligible." 186

Regarding the term "terrorism" found in section 19 of the Immigration Act, the Court ruled that the term provides a sufficient basis for adjudication and, hence, is not unconstitutionally vague. ${ }^{187}$ The Court acknowledged that the term "terrorism" is notoriously difficult to define and that they would not endeavor to do so in this decision. ${ }^{188}$ Nonetheless, the Court did conclude that even though the term is unsettled, this does not mean that they cannot set the proper boundaries of legal adjudication. 189 The Court considers the International Convention for the Suppression of the Financing of Terrorism, GA Res. 54/109, December 9, 1999, which approaches the definitional problem in two ways to be suitable for the task: first, through a functional definition under Article 2(1)(a) that utilizes the definitions of terrorism that are found in nine treaties that cover a range of terrorist activities, such as aircraft hijackings, terrorist bombings, and so on; and, second, it supplements the offence-based list with a stipulative definition of terrorism found in Article 2(1)(b). ${ }^{190}$

Any .... act intended to cause death or serious bodily injury to a civilian, or to any other person not taking an active part in the hostilities in a situation of armed conflict, when the purpose of such act, by its nature or context, is to intimidate a population, or to compel a government or an international organization to do or to abstain from doing any act. ${ }^{191}$

The Court argued that this definition catches the essence of what the world understands to be terrorism. ${ }^{192}$ It is concluded that this definition is sufficiently certain under the Immigration Act to be workable, fair, and constitutional. ${ }^{193}$

Amnesty International, an intervenor in the Suresh case before the SCC, has argued that international law rejects deportation to torture and that Canada is bound under the norm of customary and conventional international law to the principle of non-refoulement. ${ }^{194}$ Amnesty International has argued that the SCC judgement is inconsistent with Canada's absolute obligation under international law not to deport anyone to torture. Accordingly, Amnesty International has continued to advocate that Canada should amend its laws to bring them in line with its obligations under international law. ${ }^{195}$

\subsubsection{Application under s. 83.28 of the Criminal Code (Re)}

In Application under s. 83.28 of the Criminal Code (Re) 2004 SCC 42, the Supreme Court of Canada considered the constitutionality of the Investigative Hearing, s. 83.28 of the Criminal Code. ${ }^{196}$ This case is a companion to Vancouver Sun (Re), [2004] 2 S.C.R. 332, 2004 SCC 43 (the "media appeal"), which was released concurrently with Application under s. 83.28 of the Criminal Code (Re). ${ }^{197}$ This was the first case in which the SCC had to address the constitutional validity of the Anti-Terrorism Act 2001. It is important to point out that the Anti-Terrorism Act was a legislative response to the $9 / 11$ terrorist attacks in the US and similar legislative responses that took place in the US and UK. ${ }^{198}$

The subject of this appeal dealt with the invocation of s. 83.29 Criminal Code provisions for conducting an Investigative Hearing relating to alleged acts of terrorism that took place on 23 June

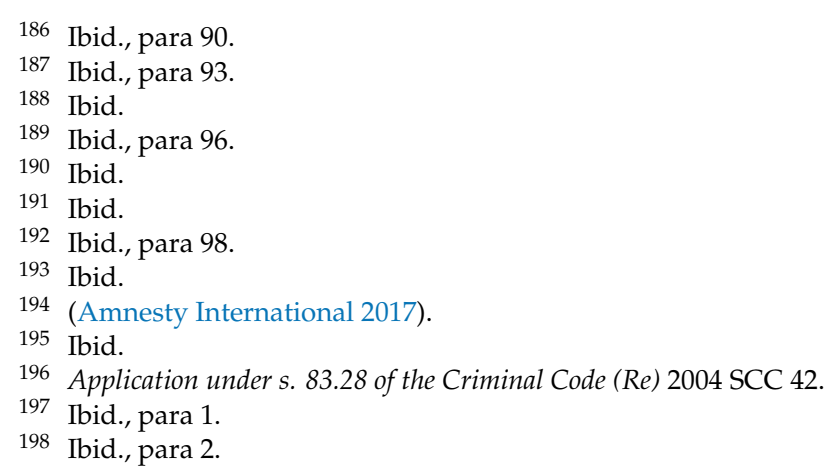


1985. One was an explosion at Narita Airport in Japan that killed two baggage handlers and injured four others while baggage was being transferred to Air India Flight 301 . The other was a second explosion that took place less than one hour later on board Air India Flight 182 that crashed off the west coast of Ireland that killed all 329 passengers and crew. These incidents were among the most deadly terrorist incidents in modern history and the Air India bombing was the worst terrorist attack involving an aircraft on record until the coordinated attacks that took place in the United States on 11 September 2001. ${ }^{199}$

On 6 May 2003, the Crown brought an ex parte application that the appellant attend an Investigative Hearings pursuant to s. 83.28 of the Criminal Code. The British Columbia Supreme Court granted the application and issued an order to gather information on the basis of an affidavit by a member of the RCMP Air India Task Force. ${ }^{200}$ The appellant sought leave to challenge the constitutional validity of s. 83.28 of the Criminal Code.

The Supreme Court considered five constitutional questions related to s. 83.28 and an additional three other issues related to the conduct of the Investigative Hearing. ${ }^{201}$ It began its analysis by considering the purpose of the legislation and came to the conclusion that it is the "prosecution and prevention of terrorist offenses." ${ }^{202}$ The Supreme Court goes on to note that

At its core, s. 83.28 permits the investigation of terrorism offences, at both a pre- and post-charge stage through testimonial compulsion on the part of the named witness. Consequently, the purpose of the provision is to confer greater investigative powers upon the state in its investigation of terrorism offences. ${ }^{203}$

The Court identified two ambiguities in the legislation: the first is the role of counsel and the second is the threshold for relevance and admissibility. ${ }^{204}$ The Court further notes its preference is to take a broad purposive interpretative approach to s. 83.28, "which accords with the presumption of constitutional validity", as required by the modern principle of statutory interpretation. ${ }^{205}$

The appellant contended that $\mathrm{s} .83 .28$ violated their absolute right to silence and their right against self-incrimination. ${ }^{206}$ Here, the Supreme Court sees the role of the judge in an investigative hearing as pivotal. After underscoring the significance of the independence of the judiciary to Canadian law, the rule of law, and its constitutional foundations, the Court states,

The function of the judge in a judicial investigative hearing is not to act as "an agent of the state", but rather, to protect the integrity of the investigation and, in particular, the interests of the named person vis-à-vis the state. ${ }^{207}$

Accordingly, the Court ruled that "A failure on the part of a hearing judge to exercise his and her discretion in this manner [to provide the witness with all of the constitutional guarantees of the Charter] will constitute a reviewable error." 208 In the companion Vancouver Sun (Re) case, the Supreme Court ruled that "judicial investigative hearings are to be held presumptively in open court and that the onus was on the Crown to rebut that presumption under the test laid out in Dagenais v. Canadian Broadcasting Corporation [1994] 3 S.C.R. 835, and R. v. Mentuck, [2001] 3 S.C.R. 442, 2001 SCC 76." ${ }^{209}$ The

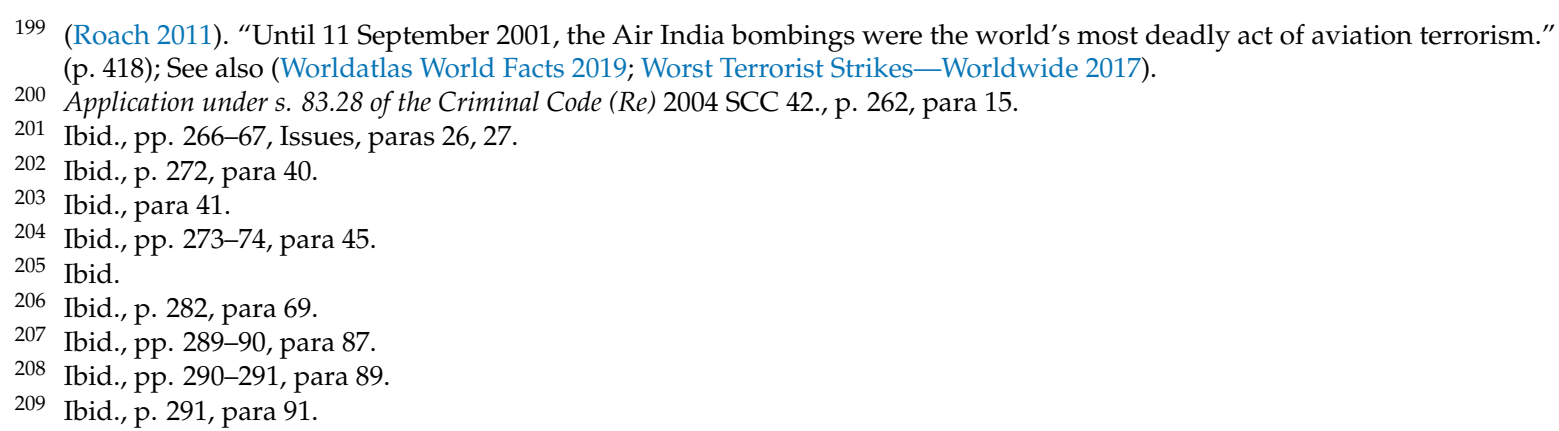


presumptive openness of the judicial investigative hearings is a further shield for the independence and impartiality of the judiciary in these proceedings.

The majority opinion in this judgement ruled that the appeal was dismissed because s. 83.28 does not infringe on the Charter and does not infringe on the independence and impartiality of the judiciary. ${ }^{210}$ It is important to note that dissenting opinions of Justices Bastarache and Deschamps and of Justice Binnie were not on the constitutional validity or its possible compromise of judicial independence or impartiality; rather, it was differences of opinion on the necessity of the openness of the investigative hearing and whether the circumstances of the current appeal constituted an abuse of process. ${ }^{211}$

In a case note on Application under s. 83.28 of the Criminal Code (Re), Byron M. Sheldrick has argued that the investigative hearing raises a number of problematic issues. ${ }^{212} \mathrm{He}$ has argued that "the judicial branch has been co-opted into the investigation of alleged terrorist offenses." ${ }^{213}$ Sheldrick argues that even though there are some judicial safeguards in the legislation, they are rather slim and fall below the usual evidentiary and procedural standards normally applied by the courts. ${ }^{214}$

It is important to note that s. 83.28 of the Criminal Code was part of the sunset provisions of the Anti-Terrorism Act 2001 and expired on March 1, 2007, and was not renewed but was, subsequently, reintroduced in new legislation, Bill S-7, Combatting Terrorism Act, and passed in 2013. ${ }^{215}$

Kent Roach has argued that "charter-proofing" has become the standard operating procedure for the federal government. ${ }^{216}$ Roach has stated that,

The bells and whistles of Charter-proofing-judicial authorization, derivative and use of immunity and the right to counsel-may ensure the provision of investigative hearings is not struck down by the Charter, but it does not remove the danger of abrogating the right of silence that potential suspects have long enjoyed in our adversarial system of criminal justice. $^{217}$

\subsubsection{R v. Khawaja}

R. v. Khawaja ${ }^{218}$ and Sriskandarajah v. United States of America ${ }^{219}$ raised similar legal issues with respect to the definition of terrorism on appeal and were heard conjointly by the Supreme Court of Canada. At trial, Khawaja claimed that several provisions of the Canadian Criminal Code were unconstitutional. ${ }^{220}$ The trial judge held that s. 83.01(1)(b)(i)(A), the "motive clause," which states that a terrorist activity must be an act or omission committed in whole or in part "for a political, religious or ideological purpose, objective or cause," was a prima facie infringement of s. 2(a), (b) and (d) of the Charter $^{221}$, and that it could not be justified under s. 1 of its provisions. ${ }^{222}$ The Court of Appeal found that the trial judge had erred in finding that the motive clause was unconstitutional and stated that "expressive activity that takes the form of violence is not protected under s. 2(b) of the Charter, since

210 Ibid., p. 296, paras 105-6.

211 Ibid., pp. 296-98, paras 107-12.

212 (Sheldrick 2006).

213 Ibid., p. 79.

214 Ibid.

215 (MacRury 2012; Justice Laws Website 2018).

216 (Roach 2001).

217 Ibid., p. 136

218 R. v. Khawaja, 2012 SCC 69, [2012] 3 S.C.R. 555.

219 Sriskandarajah v. United States of America, 2012 SCC 70, [2012] 3 S.C.R. 609.

220 Criminal Code, ss. 83.01(1), 83.03(a), 83.18, 83.18(1), 83.18(3)(a), 83.19, 83.2 and 83.21(1).

221 Sections 2 of the Canadian Charter of Rights and Freedoms covers Fundamental Freedoms and subsections (a), (b) and (d) are: (a) freedom of conscience and religion; $(b)$ freedom of thought, belief, opinion and expression, including freedom of the press and other media of communication; and $(d)$ freedom of association.

222 Section 1 of the Charter, Guarantee of Rights and Freedoms, states: " . . guarantees the rights and freedoms set out in it subject only to such reasonable limits prescribed by law as can be demonstrably justified in a free and democratic society." 
violence is destructive of the very values that underlie the right to freedom of expression. For the same reason, threats of violence are not protected by s. 2(b)."223

The SCC considered the constitutionality of the s. 83.18 of the Criminal Code. The appellants challenged this provision on its vagueness and overbreadth. Writing the unanimous judgement for the Supreme Court, Chief Justice Beverley McLachlin opined that a principle of fundamental justice is that criminal laws cannot be overbroad. The appellants asserted that "the combined effect of the definition of terrorist activity (s. 83.01(1)) and the provisions prohibiting participation in terrorist activity (s. 83.18) result in overbreadth, by criminalizing conduct that creates no risk of harm and is only tenuously connected to Parliament's objective of preventing terrorist activity." 224 "The appellants argue that the law is too broad because it is grossly disproportionate to the objective that it seeks to achieve."225 Chief Justice McLachlin considered whether "overbreadth" and "grossly disproportionate" are distinct constitutional doctrines that breach the principles of fundamental justice, but she decided instead to consider them together, without deciding whether they are distinct constitutional doctrines. ${ }^{226}$ She applied a three point analysis in doing so, by: (1) examining the scope of the law; (2) determining the objectives of the law; and (3) asking whether the means selected by the law are broader than necessary to achieve the State's objective and whether the impact of that law is grossly disproportionate to that objective. ${ }^{227}$ Chief Justice McLachlin notes that the purpose of the terrorism provisions of the Criminal Code is "'to provide a means by which terrorism can be prosecuted and prevented' (Application under s. 83.28 of the Criminal Code (Re), at para 39)—not to punish individuals for innocent, socially useful or causal acts which absent any intent, indirectly contribute to a terrorist activity."228 This requires a high mens rea threshold that includes the person knowingly participating in and contributing to a terrorist activity, but that their actions must be undertaken for the purposes of enhancing the ability of a terrorist group to facilitate or to carry out terrorist activity. ${ }^{229}$

The SCC ruled that the scope of the law under s. 83.18 was much narrower than claimed by the appellants and that it did not include "innocent or socially useful conduct that is undertaken absent any intent to enhance the abilities of a terrorist group to facilitate or to carry out a terrorist activity" or "for conduct that a reasonable person would not view as materially capable of enhancing the abilities of the terrorist group to facilitate or carry out a terrorist activity."230

On the question of whether s. 83.18 of the terrorism provisions of the Criminal Code are broader than necessary or have a grossly disproportionate impact on the prosecution or prevention of terrorist activities, it is noted in the judgement that the actus reus does not include "conduct that a reasonable person would not view as capable of materially enhancing the abilities of a terrorist group to facilitate carrying out a terrorist act." 231 In addition, the high mens rea requirement that involves a "specific intent to enhance the abilities of a terrorist group to facilitate or carry out a terrorist activity" 232 helps to ensure to those who are complicit in terrorist activities are found guilty under this provision of the Criminal Code. The Crown is required to prove both of these elements beyond reasonable doubt in order to secure a conviction of anyone charged under these provisions. Accordingly, the judgement reached was that when the "tailored reach of the section is weighed against the objective, it cannot be said that the selected means are broader than necessary or the impact of the section is disproportionate."233 Indeed, the court rules that,

\footnotetext{
223 R. v. Khawaja, para 17.

224 Ibid., para 35.

225 Ibid., para 38

226 Ibid., para 40.

227 Ibid.

228 Ibid., para 44

229 Ibid., para 45

230 Ibid., para 53.

231 Ibid., para 57

232 Ibid.

233 Ibid., para 62.
} 
The criminalization under s. 83.18 of a broad range of interactions that have the potential to-and are intended to-materially enhance the abilities of terrorist groups is not grossly disproportionate nor overly broad in relation to the objective of prosecuting, and in particular, of preventing terrorism. ${ }^{234}$

Accordingly, the court concluded that s. 83.18 does not violate Section 7 of the Charter.

The appellant further asserted that the terrorism provisions of the Criminal Code infringe on s. 2 guarantees of freedom of expression, freedom of religion, and freedom of association in the Charter. The Supreme Court noted that a law may infringe on a right by either its purpose or its effect. ${ }^{235}$ The appellants contended that the terrorism legislation, by its very purpose, imposes limits on the s. 2 rights in the Charter.

However, the crucial point is that violent activities are not protected under s. 2(b) of the Charter. ${ }^{236}$ Although this was acknowledged by the appellants, they argued, nonetheless, that the violence exception should be construed narrowly to include only expressive activity that only involves violence. ${ }^{237}$ The SCC, in a series of previous cases, has taken the position that the violence exception under s. 2(b) also includes threats of violence. As the court noted in the Greater Vancouver Transportation Authority, "violent expression or threats of violence fall outside the scope of the s. 2(b) guarantee (para. 28 (emphasis added))." 238

The Supreme Court then considered whether the effect of the law violated freedom of expression. The appellants argued that the s. 83.01(1)(b)(i)(A), the "motive clause," is unconstitutional on two grounds:

(1) it has the effect of chilling the exercise of freedom of expression, freedom of religion, and freedom of association;

(2) it would legitimize law enforcement action aimed at scrutinizing individuals based on their religious, political, and ideological beliefs. ${ }^{239}$

The trial judge accepted these arguments and severed the motive clause from the trial. However, the Court of Appeal disagreed and restored it. On the first point, Chief Justice McLachlin found that the appellants had not demonstrated that the motive clause had a chilling effect on the expression of religious or ideological views. The point was made that the trial judge's finding that there was a chill in the expression of religious and ideological views was, the SCC found, a consequence of the "post-9/11" climate of suspicion, rather than from the motive clause in the terrorism legislation. ${ }^{240}$

The SCC observed further that a patently incorrect understanding of the terrorism provisions cannot be a basis for a finding of unconstitutionality. ${ }^{241}$ Furthermore, the Court also argued that police misconduct, such as profiling based on religion or ideology, is not a chill that is a result of the terrorism legislation. ${ }^{242}$ The Court goes so far as to state that "the impugned provision is clearly drafted in a manner that is respectful of diversity, as it allows for the non-violent expression of political, religious or ideological views." ${ }^{243}$

In conclusion, the Supreme Court ruled that the impugned terrorism provisions within the Criminal Code do not infringe either s. 7 or s. 2 of the Charter.

\footnotetext{
234 Ibid., para 63

235 Ibid., para 65.

236 Ibid., para 67

237 Ibid., para 68

238 Ibid., para 70

239 Ibid., para 76.

240 Ibid., para 81.

241 Ibid., para 82.

242 Ibid., para 83.

243 Ibid., para 83.
} 
Kirk Makin, justice reporter, for The Globe $\mathcal{E}$ Mail, Canada's national newspaper, described the Khawaja judgement of the SCC in the following terms:

The landmark ruling means that an Islamic terrorist from Ottawa-Mohammed Momin Khawaja-will spend his life behind bars for aiding a violent jihadist group based in England.

It also paves the way for the extradition of two other Ontario men wanted in the U.S for helping acquire arms to be used by Sri Lankan terrorists.

The rulings were a vote of confidence for a contentious wave of legislation enacted following the Sept. 11 attacks in New York City.

The court issued its rulings on three terrorism-related cases simultaneously.

The appeals focused on free speech, religious freedom and the right of an individual to remain in the country and provided the final word on the constitutionality of key provisions in Canadian anti-terrorism laws. ${ }^{244}$

\section{A Comparative Legal Analysis of the Judicial Reasoning on These Leading Terrorism Cases}

The first part of this article demonstrated that the definition of terrorism in the UK, the US, and Canada differed substantially in significant ways. For instance, the UK had the broadest definition of terrorism; the US had the most unique definition, with one for international terrorism and another for domestic terrorism; and Canada had the most international definition of what constitutes a terrorist offense or activity.

This second part of this article considered the Supreme Court jurisprudence on terrorism in each of these countries. This part of the article will undertake a comparative jurisprudential analysis of some of these leading terrorism cases across these three common law countries. The comparative jurisprudential legal analysis will begin by first distilling the underlying legal principles from the ratio decidendi or rationes decidendi in each of these judgements. ${ }^{245}$ There is no one method of identifying the ratio decidendi or rationes decidendi in a case. ${ }^{246}$ The legal principles derived herein were distilled from the Supreme Court cases summarized in some detail in the previous part of the article immediately above.

After the legal principles are identified for each of the SC cases, they are analyzed to determine whether they are similar and consistent or dissimilar and inconsistent. It is argued that if the legal principles emerging from some of the leading judgements of these SCs are similar and consistent, then the jurisprudential trend is towards convergence. If the legal principles are dissimilar and inconsistent, then the jurisprudential trend across these three jurisdictions is towards divergence.

244 (Makin 2012).

245 According to USLegal.com (USLegal n.d.), "Ratio decidendi (plural rationes decidendi) is a Latin phrase meaning "the reason for the decision." Ratio decidendi refers to the legal, moral, political and social principles on which a court's decision rests. It is the rationale for reaching the decision of a case. It is binding on lower courts through the principle of Stare decisis. Ratio decidendi is a helpful tool for a lawyer." It goes on to state the method for discerning the ratio decidendi of a case by: Ratio is a ruling on a point of law and the decision on a point of law depends on facts of a case. Culling out ratio from a judgment is difficult. A thorough reading of an entire judgment is required to identify a ratio. Ration decidendi can be determined or identified in the following ways:

- By distinguishing material facts from unimportant facts.

- $\quad$ By discovering the precedents applied to identify the court's approach.

- By restricting analysis to the majority opinions.

- $\quad$ By reading out subsequent decisions and considering it at several levels.

USLegal, Ratio Decidendi Law and Legal Definition 1997-2016. [Emphasis added.]; Julius Stone, Precedent and Law: Dynamics of Common Law Growth. (Sydney: Butterworths, 1985).

246 (Crossley 2014); (Holland and Webb 2016) state that, "Various judges and academics have tried to define what we mean by ratio decidendi. It is a surprisingly difficult problem." p. 190; (Smith 2016) states, "Although there is nothing like universal agreement on point, the ratio decidendi of a case can be defined as the material facts of the case plus the decision thereon." pp. 95-96. I have adopted a variety of approaches and methods in deducing the ratio decidendi from each of these cases and their underlying legal principles. 


\subsection{Emerging Legal Principles and Jurisprudential Trends on Terrorism in the United Kingdom}

From the ratio decidendi in the R. v. Gul judgement of the UKSC, the following legal principle was identified:

International law is often necessary and essential to deciding legal issues in domestic law.

The ratio in the Beghal (Appellant) v Director of Public Prosecutions (Respondent) case yielded the following legal principle:

The principle of legality can be satisfied when there are adequate safeguards in place to protect individual rights from the risk of arbitrary misuse of power.

The legal principles articulated in these UK Supreme Court cases suggest that counter-terrorism statutory measures put into place have met the standards of the law in the United Kingdom. For example, in Beghal v. DPP, the UK Supreme Court ruled that the principle of legality can be satisfied when there are adequate safeguards in place to protect individual rights and the risk of arbitrary misuse of power. R. v. Gul provides a general legal principle for resolving legal issues in domestic law, with the maxim that international law is often necessary and essential to deciding legal issues in domestic law. Domestic or municipal and international laws are obviously closely interlinked, especially in monist or unitary legal systems, but also in dualist systems. Accordingly, a legal principle such as this one should prove to be a useful "rule of thumb" for anyone involved in any legal proceedings. Given the nature of terrorism and its often transnational and international character, this legal principle is especially apropos.

The consistent overall trend of these UK Supreme Court judgements is, again, like the US and Canada, to be supportive of the UK's government administration's counter-terrorism measures and efforts. It is noteworthy that the long years of experience with terrorism in the UK with the Provisional Irish Republican Army (IRA) would have an impact on the UK's legal and operational approaches to combatting terrorism, in comparison to either the US or Canada.

\subsection{Emerging Legal Principles and Jurisprudential Trends on Terrorism in the United States}

An examination of the ratios decidendi in the Hamdan v. Rumsfeld judgement discerned the following legal principle:

The US President's use of military commissions must comply with the American common laws of war, and the Uniform Code of Military Justice (UCMJ), Common Article 3 of the Geneva Conventions of 1949, and the "rules and precepts of the law of nations."

The ratio in the Holder $v$. Humanitarian Law Project results in the following legal principles arising:

Prohibiting material support for foreign terrorist organizations, in the form of monetary contributions, other tangible aid, legal training, and political advocacy, does not infringe the rights in either the First or Fifth Amendments.

The consideration of foreign policy implications relevant to a case may be pertinent to deciding determinative questions of law.

The legal principles emerging from these two cases demonstrate that the US President and the US government cannot skirt essential constitutional liberties. For instance, the US Supreme Court ruled that the US President's "war powers" do not remove constitutional safeguards to essential liberties. Likewise, the US President's authorization of Military Commissions to try "enemy combatants" must comply with American and international laws, such as the Uniform Code of Military Justice or Common Article III of the 1949 Geneva Conventions. The USSC recognized that the "War on Terror" is a non-conventional war that could last for decades. This would have implications for all those "prisoners 
of war," or the US government's preferred label of "enemy combatants," who have been captured and held in detention for the duration of the war. The "War on Terror" or Overseas Contingency Operations could last for decades if not generations. How and when does a non-conventional armed conflict or war end? ${ }^{247}$

It is a given that the battle against terrorism requires coordinated and sustained efforts among States. One of the major efforts underway to address the threat of terrorism is to limit its funding and financing. The United Nations has sponsored the 1999 International Convention on the Suppression of the Financing of Terrorism in an effort to limit terrorists' and terrorist organizations' access to funds for their operations. $^{248}$ The US Congress has issued a prohibition on any material support for foreign terrorist organizations and the US Supreme Court has ruled that this does not constitute an infringement on either the First or the Fifth Amendment.

There have been a number of cases that have gone up to the USSC that have sought to seek redress for having been detained following the 9/11 terrorist attacks in the United States. Each one of these cases has failed, principally because both federal and state officials have qualified immunity shields against money damages. ${ }^{249}$

Overall, not unsurprisingly, it appears that if there are any trends, then the judgements of the USSC appear to be in favor of the US government, but, as evident from Hamdan v. Rumsfeld, this is not always the case. There are outer boundaries and parameters that the political executive cannot breach in a liberal democracy. In the struggle against terrorism, the USSC has been deferential to the President and Congress in its "War on Terrorism," 250 but only up to a point. It is also important and relevant to point out that the in February of 2009, the International Commission of Jurists urged the then US President, Barack Obama, to drop the phrase "War on Terror."251

The commission said the term had given the Bush administration "spurious justification to a range of human rights and humanitarian law violations," including detention practices and interrogation methods that the International Committee of the Red Cross has described as torture. ${ }^{252}$

\subsection{Emerging Legal Principles and Jurisprudential Trends on Terrorism in Canada}

From the Suresh decision, there are at least four legal principles that emerge from the ratio decidendi in the SCC reasons for their judgement. They include:

Deportation to torture requires a careful consideration of a wide set of factors and the resulting balance struck will be dependent, at least in part, on the personal situation and circumstances of the potential deportee, the general circumstances, including the danger the potential deportee poses to Canadians and the security of Canada, and the threat of terrorism in Canada.

Barring extraordinary circumstances, deportation to torture will generally violate the principles of fundamental justice protected by section 7 of the Charter.

The term "terrorism" found in section 19 of the Immigration Act, is not constitutionally vague and provides a sufficient basis for adjudication. The International Convention for the Suppression of the Financing of Terrorism definitional approach to terrorism is

\footnotetext{
247 The obvious answer to this question might be when terrorism is completely eradicated. But, is that even possible, let alone feasible in a liberal democratic society or, indeed, in any type of society? It is akin to suggesting that crime can be eradicated and, hence, law enforcement will never be required in any society.

248 (United Nations Treaty Series 1999).

249 (Epps 2016; Vladeck 2017; Hamilton 2004).

250 (Wilson and Kamen 2009; Burkeman 2009; Williams and Epstein 2017).

251 (International Commission of Jurists 2009).

252 (Wilson and Kamen 2009).
} 
endorsed that utilizes two methods: first, through a functional definition under Article 2(1)(a) that is found in the nine treaties that cover the range of terrorist activities such as aircraft hijackings, terrorist bombings, etc., and, second, offers a stipulative definition of terrorism found in Article 2(1)(b).

Fundamental justice requires that a person facing deportation to torture under section 53(1)(b) must be informed of the case to be met. This includes the full disclosures of documents, save those that must remain confidential for public security. The person should also have the right to provide written submissions that must be considered by the Minister. If the Minister is relying on the written assurance of a foreign government that a person would not be tortured, then, the appellant must have an opportunity to present evidence and to make submissions as to the value of those assurances. The Minister must present reasons for his decision.

Perhaps the third among these four legal principles found in Suresh is the most salient, given that it provides a definition of terrorism that is not constitutionally vague and that is rooted in public international law. Additionally, as noted earlier, it is still very much applied in immigration and refugee law in Canada, despite the existence of a "crime of terrorism" in the Canadian Criminal Code. 253

Likewise, from an examination of the ratios in the SCC's judgement in Application under s. 83.28 of the Criminal Code (Re), the following legal principle was identified:

Judicial investigative hearings are to be held presumptively in open court and that the onus is on the Crown to rebut the presumption. The presumptive openness of judicial investigative hearings is a further shield for the independence and impartiality of the judiciary in the proceedings.

From an examination of the ratio in the SCC's judgement in $R v$. Khawaja, several legal principles can be identified. The first is that

There is a high mens rea requirement when a person knowingly participates in contributing to a terrorist activity. The person's actions must be undertaken for the purposes of enhancing the ability of a terrorist group to facilitate or to carry out terrorist activity.

And, the second is that

Violence or threats of violence undermine the rule of law and they take away freedom of choice while undermining freedom of action. Violence and the threat of violence undermine the very values and social conditions that are necessary for the continued existence of the freedom of expression.

What is evident from these leading cases on terrorism is that the SCC has demonstrated it understands the serious threat that terrorism presents to Canadian society and that the State, specifically the political executive, must adapt new legal tools in order to be able to prosecute and to prevent terrorism. This is perhaps most evident in the Suresh decision, where the SCC decided that under "extraordinary circumstances," and provided the government followed appropriate procedures and did not violate the principles of fundamental justice, a person could be deported to torture. This, in itself, is an extraordinary decision, given the generally accepted notion in international law, and as recognized by the SCC, that there is a prohibition against sending anyone back to torture. Indeed, it is considered to be a peremptory norm. ${ }^{254}$ Just as significantly, the SCC in Suresh reached the

\footnotetext{
253 See footnotes 54 and 69 above and Alam, Shamsul v. Minister of Citizenship and Immigration. (F.C. no. IMM-5226-17), Fothergill, 17 September 2018; 2018 FC 922, paragraphs 25-28, pp. 12-14.

254 (De Wit 2004).
} 
judgement that the terms "danger to the community" and "terrorism," as found in the Immigration Act, were not constitutionally vague. The SCC endorsed a particular definitional approach to terrorism as found in the International Convention for the Suppression of the Financing of Terrorism's two-pronged approach, one a functional and the other by a stipulative definition, as being adequate for adjudicative purposes. Suresh sent a clear message that the SCC recognized that the struggle against terrorism would require the government to have greater legal tools in this area if it was going to succeed in its goal of prosecuting and preventing terrorism in Canada.

It is worth noting that for every one of these cases, the SCC dismissed the appeals and constitutionally upheld the government's expanded authority and powers to combat terrorism in all its manifestations. Application under s. 83.28 of the Criminal Code is most illustrative of this point because it approved the use of Investigative Hearings to gather evidence compulsively regarding possible terrorist activities, as well as ongoing prosecutions. Nevertheless, the SCC did temper, through its interpretation, the legislation in various ways to ensure that it conformed to fundamental justice, due process, and the Charter. However, the overriding trend has been to uphold the government's powers to confront the threat of terrorism square on.

\subsection{The Legal Principles Identified Across These Three Jurisdictions Compared}

An examination of the 12 legal principles identified in the seven SC cases in these three common law jurisdiction reveals that they are similar in some notable respects. The legal principles enunciated here are essentially based on the "rule of law" and anchored on the protection of fundamental human rights and human dignity. Moreover, they underscore the significance of international law; that 'legality' requires the safeguarding of individual human rights; that foreign policy considerations may be relevant to deciding questions of law; that "terrorism" is not a "constitutionally vague" legal term; that barring 'material support' for terrorist organizations does not violate fundamental human rights; and that violence and threats of violence undermine the "rule of law" and the very values and social conditions necessary for the freedom of expression; among a number of others. When these 12 legal principles are read together, they do not appear to be inconsistent. On the contrary, read together, they appear to be highly consistent.

It is reasonable to conclude, then, that these 12 legal principles indicate that there appears to be a convergence in the law of terrorism among these three common law jurisdictions and not a divergence in the jurisprudence that would indicate that these countries may be interpreting what constitutes "terrorism" differently, given the significant differences in their statutory definitions of terrorism.

\subsection{Comparisons Across These Three Common Law Jurisdictions}

On the face of it, these cases are similar in a number of ways and not simply because they all deal with foreign terrorist organizations and the provision of material support for these terrorist groups, albeit in the case of $R v$. Gul, the appellant was involved in the dissemination of videos that espoused support for Al-Qaida, the Taliban, and other prescribed groups, and that praised the bravery and martyrdom of those carrying out the attacks against Coalition Forces and that espoused the jihad cause. ${ }^{255}$ Additionally, in the Holder v. Humanitarian Law Project, it was in the hope of being able to provide material support and resources for the humanitarian and political wings of designated foreign terrorist organizations, the PKK and LTTE. It is also interesting to point out that four of the appellants/plaintiffs in these cases were nationals of their countries. Indeed, Mohammad Momin Khawaja was born in Canada; Suresh Sriskandarajah and Piratheepan Nadarajah, in the conjoined case with Khawaja, are Canadian citizens; and Mohammed Gul was a naturalized British citizen who had lived most of his life in the UK. The plaintiffs in the Holder v. Humanitarian Law Project were either US citizens or naturalized citizens. In at least two of these cases dealing with terrorism, then, it is not

255 Ibid., p. 2, para 2. 
a foreign national who is seeking to perpetrate the terrorist activities on their host state but, rather, citizens who have been radicalized to a political, religious, or ideological cause that espouses violence as the means of achieving their ultimate goal.

The plaintiffs in the Humanitarian Law Project case, of course, sought what they considered was a lawful, humanitarian, and peaceful means of trying to resolve the protracted violent struggle between a perceived legitimate cause, the self-determination of ethnic and racial minorities, who are being oppressed, it was argued, within their existing states and societies. Such idealism seems oblivious, if not blind, to the reality and practicalities of how those who are so committed to their cause that they are prepared to use any means necessary, including extreme violence perpetrated against the innocent, to spread fear and chaos across their own or other societies in order to achieve their political, social, and economic objectives.

Suresh dealt with whether Convention refugees could be refouled to their country of nationality, in this instance, Sri Lanka, to face possible torture. The SCC, in both instances, ruled that in extraordinary circumstances, this was possible provided that due process was rigorously followed and there were no violations to the principles of fundamental justice. Regardless of one's view on these legal issues, these are enormously difficult and courageous judgements on the part of the SCC, given the widely held belief that there is a prohibition to sending anyone back to be or at a possible risk of being tortured under international law. Sending a Convention refugee back to the possibility of torture only exacerbates the judgement given it violates the central principle on which the entire international refugee protection regime is premised, non-refoulement; that is, no one should be sent back to a country where they might face persecution. ${ }^{256}$ Torture in many circumstances can, of course, amount to persecution under the 1951 Convention relating to the Status of Refugees. It is evident that the SCC ruled that when someone is such a "danger to the security of Canada", the safety and protection of Canadian citizens takes precedence over the possible risk of torture that an individual may face upon their return to their country of nationality or country of habitual residence. This is clearly an astonishing decision by the SCC that has brought it enormous criticism from all quarters.

The other relevant similarities in these cases are that the appellants/plaintiffs essentially employ the same constitutional arguments to try to strike down the impugned legislation in their respective jurisdictions. For example, in $R$. v. Khawaja and in the companion case Sriskandarajah v. USA, the appellants argued that the terrorism provisions of the Canadian Criminal Code were both vague and overbroad. In addition, they argued that the terrorism provisions infringed on their section 2 rights in the Canadian Charter of Rights and Freedoms. Likewise, in the Holder v. Humanitarian Law Project, the plaintiffs argued that the impugned provisions of the terrorism legislation were vague and violated their First Amendment rights to freedom of expression and freedom of association and their Fifth Amendment rights to due process, specifically in the prohibition of any form of material support to any listed foreign terrorist organizations without proper consideration of the intent of the material support for lawful and humanitarian purposes.

Again, in $R v$. Gul, the appellant argued that the terrorism definition was overly broad and did not conform to the general understanding of international norms. The consistency in terms of the constitutional challenges against the terrorism provisions within these three jurisdictions is striking, if not somewhat predictable, given the definition of terrorism across these three jurisdictions and the limited range of persuasive constitutional arguments that can be presented to challenge these legal definitions of terrorism, as well as to provide a legal defense of the appellants/plaintiffs against their criminal charges or in the case of the Humanitarian Law Project case to challenge the constitutionality of the provision of material support or other resources for lawful humanitarian purposes to designated foreign terrorist organizations without being prosecuted under the federal criminal code.

256 (Lauterpacht and Bethlehem 2003). 
The most obvious similarity in these seven cases is, of course, that the three States' Supreme Courts set aside all of the appeals, with some minor variations. The two most notable exceptions being, of course, the judgements in Hamdan v. Rumsfeld, in favour of the appellant, and Suresh, where, despite the ruling that a refugee could be sent back to a possible risk of torture in exceptional circumstances, the Court found the procedures followed in this case contrary to fundamental justice. Nonetheless, the SCs ruled that the respective statutory definitions of terrorism were constitutionally valid..$^{257}$

Thus, these SC cases were the landmark judgements that established the legal validity and constitutional legitimacy of the statutory definitions of terrorism within their respective jurisdictions. However, in each instance, there were some notable indications that further work and consideration were necessary to the existing law. In Canada and the UK, these were expressed in further commentaries following the judgements and in the US, in the dissenting opinion of the Justices of the Supreme Court, thus setting the stage for the necessary further work required for refining the existing statutory definitions of terrorism.

\section{Conclusions}

The current world trends indicate that terrorism is likely to be around for quite some time, despite the concerted efforts of the United Nations, the international community, and its' member States. The United States has taken a lead role in this regard with both its "War on Terror" and, now, "Overseas Contingency Operations," and with the support of its key allies, the UK and Canada. ${ }^{258}$ Indeed, current US President Donald Trump has stated that he intends to defeat "radical Islamic terrorism," a highly emotive and politically charged phrase that others suggest is most unlikely, given the unconventional nature of terrorism. ${ }^{259}$ The immediate impact of the $9 / 11$ terrorist attacks in the United States was the invasion of Afghanistan in 2001. The turmoil has continued ever since in the Middle East and, in fact, the situation has deteriorated, with the war in Syria becoming the world's most deadly armed conflict. With the ongoing armed conflicts and instability in the Middle East, it is not surprising to find that this region has experienced the highest number of terrorist attacks over any other. ${ }^{260}$ However, the UK, the US, and Canada have also had to face terrorist incidents and, as a consequence, have had to respond to ensure that their societies remain safe and secure as much as is reasonably possible.

All three States have passed extensive legislation criminalizing terrorism, including defining what, in fact, constitutes the offense of terrorism. The definitions of terrorism are distinctive, but nonetheless, similar in some respects. The jurisprudence on terrorism in these three jurisdictions and, in particular, the legal principles derived from the ratio or rationes decidendi of these judgements, indicate that despite the definitional differences, there appears to be convergence with respect to the legal principles emerging from the jurisprudence.

A comparative analysis of the legal principles that emerge from the ratios of each of these respective Supreme Court judgements on terrorism reveals a wide range of principles of law that are, in some instances, particularly applicable to their own State's legal system. What is most evident is that these legal principles are similar and, if taken as a whole, entirely consistent. Accordingly, these legal principles appear to indicate that there is a convergence and not a divergence in this critically important area of domestic criminal law. This augurs well for both transnational and international counter-terrorism strategies, laws, and policies because it indicates that what appears to be emerging is a common understanding of what constitutes terrorism, at least across these three major common law jurisdictions. Moreover, these findings and conclusions also lend support to the notion that what

\footnotetext{
257 In Suresh, the SCC directed there had to be new deportation hearing consistent with the due process outlined in the reasons for their judgement. In Hamdan, the US SC held that the US President's authorized military commissions must comply with the laws of the land and international law, in particular, Common Article 3 of the 1949 Geneva Convention.

258 (US State Department 2015; Weimeng 2017; Cordesman 2016).

259 (Pramuk 2017; Feaver and Brands 2017).

260 (Dominic 2016).
} 
is emerging, not only among these common law States since $9 / 11$, but, potentially internationally, is a consensus on what constitutes terrorism. This further suggests that a Comprehensive International Convention on terrorism may now be within reach.

Furthermore, what the seven terrorism cases presented and analyzed here demonstrate, essentially, is that the Justices of these respective Supreme Courts defer to their respective government to take the lead in the battle against terrorism. The Supreme Courts are conscious of ensuring that constitutional principles and that national and international laws are adhered to when their governments' introduce and apply counter-terrorism measures to combat terrorism. Consequently, these Supreme Courts ensure that whatever measures their governments' introduce are constitutionally sound and legally valid. This may be far from revelatory or original, but it is, nonetheless, reassuring given the concerns that the judiciary might fail to serve as the bulwark or defense of civil liberties, human rights, and human dignity, given the rising tide of the "fear of terrorism" over the last two decades.

The prosecution of terrorism cases is, of course, one of the counter-terrorism strategies. The Courts, at all instances, have had to be especially vigilant in ensuring that their governments do not exceed their legal and constitutional authority and that their citizens' rights are ensured to the highest degree while their security is, at the same time, protected to the maximum degree possible. This is a fine balancing act that is entrusted to the final courts of appeal in these respective jurisdictions. Hopefully, this balance will be found and maintained despite the ongoing struggle against the terrorist onslaught in the world today.

Funding: This research received no external funding.

Conflicts of Interest: The author declares no conflict of interest.

\section{Appendix A}

Jurisprudence

Canada

Alam, Shamsul v. Minister of Citizenship and Immigration. (F.C. no. IMM-5226-17), Fothergill, 17 September 2018; 2018 FC 922,

Application under s. 83.28 of the Criminal Code (Re) 2004 SCC 42

Intisar v. Minister of Citizenship and Immigration Canada, (F. C. no. IMM-1627-18), Southcott, November 8, 2018, FC 1128,

R. v. Khawaja, 2012 SCC 69, [2012] 3 S.C.R. 555.

Rana R. Khan $v$ Minister of Public Safety and Emergency Preparedness, (F.C. no. IMM-4223-17), Norris, October 29, 2018, FC 1080.

Sriskandarajah v. United States of America, 2012 SCC 70, [2012] 3 S.C.R.

Suresh v. Canada (Minister of Citizenship and Immigration), [2002] 1 S.C.R. 3, 2002 SCC 1

United Kingdom

Beghal (Appellant) v Director of Public Prosecutions (Respondent) [2015] UKSC 49, p. 2, para 1 and 6, para 12.

$R v$ Gul (appellant) [2013] UKSC 64.

United States

Hamdan v. Rumsfeld, 548 U.S. 557 (2006)

Holder v. Humanitarian Law Project, 561 U.S. 1 (2010), 130 S.Ct. 2705. 


\section{References}

ACLU, American Civil Liberties Union. 2018. How the USA PATRIOT Act redefines 'Domestic Terrorism'. Available online: https:/ / www.aclu.org/other/how-usa-patriot-act-redefines-domestic-terrorism (accessed on 30 May 2018).

Alan, Greene. 2017. Defining Terrorism: One Size Fits All? International and Comparative Law Journal 66: 411-40.

Allyson, Mitchell. 2012. “Terrorism Defined," December. Beyond Intractability. Available online: http:/ / www. beyondintractability.org/essay/terrorism-defined (accessed on 23 April 2017).

Amnesty International. 2017. SURESH v. CANADA. Submitted by Anonymous (not verified) on Wed, 03/08/2017-20:09. Available online: https:/ / www.amnesty.ca/legal-brief/suresh-v-canada (accessed on 1 June 2018).

Ben, Saul. 2008. Defining Terrorism in International Law. Published to Oxford Scholarship Online 2010, Introduction, The Concept of Terrorism. Oxford: Oxford University Press. Available online: http:/ / www.oxfordscholarship.com/view/10.1093/acprof:oso/9780199535477.001.0001/acprof9780199535477-miscMatter-1 (accessed on 22 April 2017).

Brebner, John Bartlet. 1945. North Atlantic Triangle: The Interplay of Canada, the United States and Great Britain. New York: Columbia University Press.

Brebner, J. Bartlet. 1948. A Changing North Atlantic Triangle. International Journal 3: 309-19. Available online: http:/ / www.jstor.org/stable/pdf/40197451.pdf (accessed on 16 October 2016). [CrossRef]

Bronskill, Jim. 2018. The Canadian Press, “When Does a Criminal Act Merit a Terrorism Charge? A Look at the Law in Canada". CTV NEWS. April 24. Available online: https:/ / www.ctvnews.ca/canada/when-does-acriminal-act-merit-a-terrorism-charge-a-look-at-the-law-in-canada-1.3900378 (accessed on 31 May 2018).

Burkeman, Oliver. 2009. Obama Administration Says Goodbye to 'War on Terror'. Theguardian. March 25. Available online: https://www.theguardian.com/world/2009/mar/25/obama-war-terroroverseas-contingency-operations (accessed on 25 April 2017).

Carl Wellman. 2013. Terrorism and Counterterrorism: A Moral Assessment. Dordrecht: Springer. Available online: http:/ /www.springer.com/gp/book/9789400760066 (accessed on 25 April 2017).

Carver, Ashley. 2016. Parliamentary Attempts to Define Terrorism in Canada and Asustralia. Journal of Applied Security Research 11: 132. Available online: https:/ / www.tandfonline.com/doi/pdf/10.1080/19361610.2016. 1137173 (accessed on 31 May 2018). [CrossRef]

Chanoff, Sasha. 2016. America Already Uses Strict Refugee Vetting. Here Are the Facts. The Washington Post, October 20. Available online: https:/ / www.washingtonpost.com/opinions/america-already-uses-strictrefugee-vetting-here-are-the-facts / 2016/10/20/7988a1a8-9185-11e6-9c52-0b10449e33c4_story.html?utm_ term $=.9778 \mathrm{e} 60826 \mathrm{c} 3$ (accessed on 16 April 2017).

Charity and Security Network. 2010. Holder v. Humanitarian Law Project: Addressing the Impact of Material Support Laws on Peacekeeping Programs. June 21. Available online: https: / /www.charityandsecurity.org/ litigation/HLP (accessed on 8 October 2018).

Coco, Antonio. 2013. Crocodile Tears: The UK Supreme Court's Broad Definition of Terrorism in R. V. Mohammad Gul. EJIL: Talk! Blog of the European Journal of International Law. November 18. Available online: https:/ / www.ejiltalk.org/crocodile-tears-the-uk-supreme-courts-broad-definition-of-terrorismin-r-v-mohammed-gul/ (accessed on 3 June 2018).

Cordesman, Anthony H. 2016. With the Assistance of Max Markusen. The Uncertain Trends and Metrics of Terrorism in 2016. Centre for Strategic and International Studies. November 29. Available online: https: / / www.csis.org/analysis/uncertain-trends-and-metrics-terrorism-2016 (accessed on 26 April 2017).

Cornell University Law School. n.d.Legal Information Institute, Criminal Law. Available online: https://www. law.cornell.edu/wex/criminal_law (accessed on 16 April 2017).

Cornell University Law School. 2018a. Legal Information Institute, U.S. Code: Title 18—CRIMES AND CRIMINAL PROCEDURE. Chapter 113B-Terrorism. Available online: https://www.law.cornell.edu/uscode/text/18 (accessed on 16 April 2017).

Cornell University Law School. 2018b. Legal Information Institute, 18 U.S. Code Chapter 113B-Terrorism. Available online: https://www.law.cornell.edu/uscode/text/18/part-I/chapter-113B (accessed on 17 April 2017). 
Cornell University Law School. 2018c. Legal Information Institute, 18 U.S. Code § 2331—Definitions. Available online: https: / www.law.cornell.edu/uscode/text/18/2331 (accessed on 16 April 2017).

Crossley, Kat. 2014. How to Find the Ratio Decidendi, Survive Law. First Published in Survive Law 23 September 2013. Available online: https://www.survivelaw.com/single-post/1512-how-to-find-the-ratio-decidendi (accessed on 1 June 2018).

De Wit, Erika. 2004. The Prohibition Against Torture as an International Norm of jus cogens and its Implications for National and Customary Law. European Journal of International Law 15: 97-121. [CrossRef]

Dominic, Dudley. 2016. The Ten Countries Most Affected by Terrorism. Forbes, November 18. Available online: https:/ /www.forbes.com/sites/dominicdudley/2016/11/18/ countries-most-affectedby-terrorism/\#12deacb630d9 (accessed on 26 April 2017).

Edwards, James. 2018. Stanford Encyclopedia of Philosophy. Theories of Criminal Law, May 14. Available online: https:/ / plato.stanford.edu/entries/criminal-law/\#CriPubWro (accessed on 10 February 2019).

Epps, Garrett. 2016. Do Counterterrorism Lawsuits Stand a Chance in Court? The Atlantic, October 14. Available online: https:/ / www.theatlantic.com/politics/archive/2016/10/hasty-vs-turkmen/504086/ (accessed on 27 April 2017).

European Court of Human Rights. 2016. First Section, Application No. 4755/16, Sylvie Beghal against the United Kingdom, Lodged on 14 January. Available online: https:/ / hudoc.echr.coe.int/eng/\# $\backslash$ protect $\backslash \mathrm{T} 1 \backslash$ textbraceleft\%22itemid\%22:[\%22001-166724\%22] \protect \T1 \textbraceright (accessed on 3 June 2018).

Feaver, Peter D., and Hal Brands. 2017. Trump and Terrorism. Foreign Affairs, March/April. Available online: https:/ / www.foreignaffairs.com/articles/2017-02-13/trump-and-terrorism (accessed on 26 April 2017).

Goodwin-Gill, Guy. 2008. Forced Migration: Refugees, Rights and Security. In Forced Migration, Human Rights, and Security. Edited by Jane McAdam. Oxford: Hart Publishing, pp. 1-18.

Government of Canada. 2018. Public Safety Canada, Currently Listed Entities. Available online: https: / / www.publicsafety.gc.ca/cnt/ntnl-scrt/cntr-trrrsm/lstd-ntts/crrnt-lstd-ntts-en.aspx (accessed on 10 February 2019).

Government of Canada. 2016. "Canada-United Kingdom Political Relations," Date Modified, 23 June. Available online: https://www.canadainternational.gc.ca/united_kingdom-royaume_uni/bilateral_ relations_bilaterales/political-politiques.aspx?lang=eng (accessed on 19 December 2018).

Government of Canada. 2015. Public Safety Canada, Listed Terrorist Entities. Available online: https:/ /www. publicsafety.gc.ca/cnt/ntnl-scrt/cntr-trrrsm/lstd-ntts/index-en.aspx (accessed on 28 April 2017).

Granastein, Jack Lawrence, and Stephen Azzi. 2015. "Canada and the United States," The Canadian Encyclopedia, Date Published, March 31, 2010, Last Edited, March 4. Available online: https://www. thecanadianencyclopedia.ca/en/article/canada-and-the-united-states (accessed on 19 December 2018).

Greene, Alan. 2014. The quest for a satisfactory definition of terrorism: $R v$ Gul. Modern Law Review 77: 780-93. Available online: http:/ / dro.dur.ac.uk/17190/1/17190.pdf?DDD19+ngxn27+d700tmt (accessed on 3 June 2018). [CrossRef]

Greenwald, Glenn. 2006. The Significance of Hamdan v. Rumsfeld. Unclaimed Territory—By Glenn Greenwald, June 29. Available online: http://glenngreenwald.blogspot.com/2006/06/significance-of-hamdan-vrumsfeld.html (accessed on 8 October 2018).

Gregor, Bruce. 2018. Definition of Terrorism-Social and Political Effects. Journal of Military and Veterans Health 21. Available online: https://jmvh.org/article/definitionof-terrorism-social-and-political-effects/ (accessed on 21 December 2018).

Gus, Martin. 2017. Types of Terrorism. Hershey: IGI Global, Available online: http:/ /www.igi-global.com/chapter/ types-of-terrorism/164714 (accessed on 23 April 2017).

Hamilton, Marci. 2004. The Supreme Courts Terrorism Cases: What They Held and Why They are Important. FindLaw. July 1. Available online: http:/ / supreme.findlaw.com/legal-commentary/the-supreme-courtsterrorism-cases.html (accessed on 27 April 2017).

Hamilton Spectator. 2018. "Maybe our Definition of Terrorism Needs to Be Updated," Opinion. Hamilton Spectator. April 26. Available online: https:/ / www.thespec.com/opinion-story/8570049-maybe-our-definition-ofterrorism-needs-to-be-updated/ (accessed on 31 May 2018). 
Hardy, Keiran, and George Williams. 2011. What is 'terrorism'?: Assessing domestic legal definitions. UCLA Journal of International Law and Foreign Affairs 16: 83. Available online: https:/ / webmail-1.hermes.cam.ac. $\mathrm{uk} /$ ?_task=mail\&_action=get\&_mbox=INBOX\&_uid=270\&_part=2\&_frame=1\&_extwin=1 (accessed on 6 October 2016).

Harper, Stephen, and David Cameron. 2011. Canada-United Kingdom Joint Declaration, A Strong Partnership for the 21st Century, 22 September 2011, Rt. Hon. Stephen Harper, MP, Prime Minister of Canada, and Rt. Hon. David Cameron, MP, Prime Minister of the United Kingdom of Great Britain and Northern Ireland. Available online: https:/ / assets.publishing.service.gov.uk/government/uploads/system/uploads/attachment_data/ file/188263/uk-cda-joint-declaration.pdf (accessed on 19 December 2018).

Holland, James, and Julian Webb. 2016. Learning Legal Rules, 9th ed. Oxford: Oxford University Press.

International Commission of Jurists. 2009. Assessing Damage, Urging Action. Report of the Eminent Jurists Panel on Terrorism. Geneva: Counter-Terrorism and Human Rights. Available online: https:/ / www.icj.org/wp-content/uploads/2012/04/Report-on-Terrorism-Counter-terrorism-andHuman-Rights-Eminent-Jurists-Panel-on-Terrorism-series-2009.pdf (accessed on 25 April 2017).

Jenkins, David. 2003. In support of Canada's Anti-Terrorism Act: A Comparison of Canadian, British, and American Anti-Terrorism Law. Saskatchewan Law Review 66: 435.

Justice Canada. 2015. Department of Justice, Government of Canada, 2015. Government of Canada, Department of Justice, Memorializing the Victims of Terrorism, Definitions of Terrorism in the Canadian Context. Available online: http:/ / www.justice.gc.ca/eng/rp-pr/cj-jp/victim/rr09_6/p3.html (accessed on 23 April 2017).

Justice Laws Website. 2018. Government of Canada, Justice Laws Website 2018. Criminal Code (R.S.C., 1985, c. C-46). Available online: http:/ / laws-lois.justice.gc.ca/eng/acts/C-46/page-18.html\#h-35 (accessed on 1 June 2018).

Lauterpacht, Sir Elihu, and Daniel Bethlehem. 2003. The Scope and Content of the Principle of Non-Refoulement: Opinion. In Refugee Protection in International Law: UNHCR's Global Consultations on International Protection. Edited by Erika Feller, Volker Türk and Frances Nicholson. Cambridge: Cambridge University Press.

legislation.gov.uk. 2000. Terrorism Act 2000; 2000 Chapter 11. Available online: http:/ /www.legislation.gov.uk/ ukpga/2000/11/contents (accessed on 17 April 2017).

legislation.gov.uk. 2006. Terrorism Act 2006. Available online: http://www.legislation.gov.uk/ukpga/2006/11/ contents (accessed on 17 April 2017).

legislation.gov.uk. 2015. Counter-Terrorism and Security Act, 2015; That Includes Further Provisions Regarding Terrorism and Additional Amendments to the Terrorism Act 2000. Available online: http:/ / www.legislation. gov.uk/ukpga/2015/6/contents (accessed on 26 April 2017).

Liptak, Adam. 2010. Court Affirms Ban on Aiding Groups Tied to Terror. The New York Times, June 21. Available online: https:/ / www.nytimes.com/2010/06/22/us/politics/22scotus.html (accessed on 8 October 2018).

Lizardo, Omar A., and Albert J. Bergesen. 2003. Types of Terrorism by World System Location. Humboldt Journal of Social Relations 27: 162-92. Available online: https:/ /www3.nd.edu/ \{\}olizardo/papers/hjsr-terrorismlocation.pdf (accessed on 23 April 2017).

MacRury, Daniel A. 2012. Chair, National Criminal Justice Section, Canadian Bar Association, Letter to Kevin Sorensen, MP, Chair of the Standing Committee on Public Safety and National Security, Re: Bill S-7, Combatting Terrorism Act, November 20. Available online: https:/ /www.cba.org/CMSPages/GetFile.aspx? guid=b9e87e70-9d1c-41b0-a93e-64ee3dd0bc3d (accessed on 1 June 2018).

Makin, Kirk. 2012. Supreme Court Upholds Anti-Terrorism Laws. The Globe E Mail. Friday, December 14. Available online: https://www.theglobeandmail.com/news/national/supreme-court-to-deliver-decisionson-anti-terror-laws/article6354739/ (accessed on 1 June 2018).

Mathew, Penelope. 2008. Resolution 1373-A Call to Pre-empt Asylum Seekers? (or Osama, The Asylum Seeker). In Forced Migration, Human Rights, and Security. Edited by Jane McAdam. Oxford: Hart Publishing, pp. 19-62.

Roser, Max, and Mohamed Nagdy. 2016. 'Terrorism'. Published Online at OurWorldInData.org. Available online: https: / / ourworldindata.org/terrorism/ (accessed on 1 March 2017).

McCulloch, Tony. 2008. Canada and the Transatlantic World. Journal of Transatlantic Studies 6. Available online: http:/ / www.tandfonline.com/doi/full/10.1080/14794010801916958?scroll=top\&needAccess=true (accessed on 16 October 2017). 
McCulloch, Tony. 2011. The North Atlantic Triangle: A Canadian Myth? International Journal 66: 197-207. Available online: http:/ /journals.sagepub.com/doi/pdf/10.1177/002070201106600113 (accessed on 28 April 2017). [CrossRef]

National Constitution Centre. 2017. Hamdan v. Rumsfeld: Applying the Constitution to Guantanamo Prisoners. Constitutional Daily, June 29. Available online: https:/ / constitutioncenter.org/blog/hamdan-v-rumsfeldapplying-the-constitution-to-guantanamo-prisoners (accessed on 8 October 2018).

O’Bierne, Sean. 2015. Case Comment: Beghal v. DPP [2015] UKSC 49. UKSC Blog. October 16. Available online: http:/ / ukscblog.com/case-comment-beghal-v-dpp-2015-uksc-49/ (accessed on 3 June 2018).

Oyen, Timothy. 2017. Stare Decisis is Latin for "to Stand by Things Decided." In Short, It Is the Doctrine of Precedent. Legal Information Institute [LII]. Available online: https:/ / www.law.cornell.edu/wex/stare_decisis (accessed on 15 December 2018).

Perry, Nicholas J. 2004. The Numerous Federal Legal Definitions of Terrorism: The Problem of Too Many Grails. Journal of Legislation. Available online: https://scholarship.law.nd.edu/jleg/vol30/iss2/3/ (accessed on 30 May 2018).

Pramuk, Jacob. 2017. Trump Takes Hardline Stance against 'Radical Islamic Terrorism'. CNBC, February 28. Available online: http:/ / www.cnbc.com/2017/02/28/trump-takes-hardline-stance-against-radical-islamicterrorism.html (accessed on 26 April 2017).

Rana. 2018. Rana R. Khan v Minister of Public Saftey and Emergency Preparedness, (F.C. no. IMM-4223-17), Norris, October 29, 2018, FC 1080. Available online: https:/ /scc-csc.lexum.com/scc-csc/scc-csc/en/item/ 15647 /index.do (accessed on 10 February 2019).

Rapoport, David C., and Yonah Alexander, eds. 1982. The Morality of Terrorism: Religious and Secular Justifications. New York: Pergamon Press. Available online: http://www.sciencedirect.com/science/book/9780080263472 (accessed on 26 April 2017).

Roach, Kent. 2001. The Dangers of Charter-Proof and Crimes-Based Response to Terrorism. In The Security of Freedom: Essays on Canada's Anti-Terrorism Bill. Edited by Ronald J. Daniels, Patrick Macklem and Kent Roach. Toronto: University of Toronto Press, p. 134.

Roach, Kent. 2011. The Air India Report and the Regulation of Charities and Terrorism Financing. University of Toronto Law Journal 61: 418-22. [CrossRef]

Roach, Kent. 2018. Why the Quebec City Mosque Shooting Was Terrorism. The Globe E Mail, April 19. Available online: https: / / www.theglobeandmail.com/opinion/article-why-the-quebec-city-mosque-shooting-wasterrorism/ (accessed on 31 May 2018).

Schmid, Alex P. 2016. Links between Terrorism and Migration: An Exploration. International Centre for Counter-Terrorism-The Hague, ICCT Research Paper, May. Available online: https:/ www.icct.nl/wpcontent/uploads/2016/05/Alex-P.-Schmid-Links-between-Terrorism-and-Migration-1.pdf (accessed on 17 April 2017).

School of Law. n.d.(Boalt Hall), University of California at Berkeley. The Common Law and Civil Law Traditions. The Robbins Collection, School of Law (Boalt Hall), University of California at Berkeley. Available online: https:/ / www.law.berkeley.edu/library/robbins/CommonLawCivilLawTraditions.html (accessed on 15 December 2018).

Secretary General. 2018. "Secretary General, at Opening of the Counter-Terrorism Conference, Says that the Response to the Scourge Ought to be as Agile, Multifaceted as Threat," United Nations, Meetings Coverage and Press Releases, SG/SM/19118-L/3283, 28 June. Available online: https:/ /www.un.org/press/en/2018/ sgsm19118.doc.htm (accessed on 15 December 2018).

Seghetti, Lisa. 2015. Border Security: Immigration Inspections at Ports of Entry. Congressional Research Service. January 26. Available online: https:/ / fas.org/sgp/crs/homesec/R43356.pdf (accessed on 26 April 2017).

Sheldrick, Byron M. 2006. Judicial Independence and Anti-Terrorism Legislation in Canada: Blurring the investigative and judicial functions: Re an Application under s. 83.28 of the Criminal Code. The International Journal of Evidence and Proof 10: 75-80. Available online: http://journals.sagepub.com/doi/pdf/10.1350/ ijep.2006.10.1.75 (accessed on 1 June 2018). [CrossRef]

Smith, Anthony Terry Hanmer. 2016. Glanville Williams: Learning the Law, 16th ed. London: Sweet \& Maxwell.

Terrorism Research. n.d.Terrorism Research, International Terrorism and Security Research, What is Terrorism? Available online: http:/ / www.terrorism-research.com/ (accessed on 23 April 2017). 
The White House. 2015. President Barack Obama, The Screening Process for Refugee Entry into the United States. November 20. Available online: https:/ / obamawhitehouse.archives.gov/blog/2015/11/20/infographicscreening-process-refugee-entry-united-states (accessed on 16 April 2017).

Totenberg, Nina. 2006. 'Hamdan v. Rumsfeld': Path to a Landmark Ruling. National Public Radio Inc, npr, Special Series: Detainees at Guantanamo Bay. September 5. Available online: https:/ /www.npr.org/templates/ story / story.php?storyId=5751355 (accessed on 8 October 2018).

UK Home Office. 2016a. Proscribed Terrorist Organizations. December 16. Available online: https://www.gov.uk/ government/uploads/system/uploads/attachment_data/file/578385/201612_Proscription.pdf (accessed on 17 April 2017).

UK Home Office. 2016b. Proscribed Terrorist Organizations. December 16. Available online: https://www.gov.uk/ government/uploads/system/uploads/attachment_data/file/578385/201612_Proscription.pdf (accessed on 17 April 2017).

United Nations Office of Drugs and Crime (UNODC). 2018. “International Community Gathers in New York, Discusses Coordinated Action to Tackle Terrorism, Violent Extremism Worldwide," 27 June 2018. Available online: https:/ / www.unodc.org/unodc/en/frontpage/2018/June/international-community-gathers-innew-york--discusses-coordinated-action-to-tackle-terrorism--violent-extremism-worldwide.html (accessed on 15 December 2018).

UN News Centre. 2015. Terrorism Can Never be Justified, Participants at Joint UN Conference Conclude. November 19. Available online: http:/ / www.un.org/apps/news/story.asp?NewsID=24725 (accessed on 25 April 2017).

UNODC. n.d.The Doha Declaration. E4J University Module Series: Counter-Terrorism, Module 4: Criminal Justice Responses to Terrorism, “Defining Terrorism," The Doha Declaration: Promoting a Culture of Lawfulness, UNODC, July. Available online: https:/ / www.unodc.org/e4j/en/terrorism/module-4/keyissues/defining-terrorism.html (accessed on 15 December 2018).

UN Office of Counter-Terrorism. n.d.United Nations Action to Counter Terrorism, International Legal Instruments. Available online: http:/ / www.un.org/en/counterterrorism/legal-instruments.shtml (accessed on 26 April 2017).

United Nations Treaty Series. 1999. International Convention on the Suppression of the Financing of Terrorism. Ratified on December 9, and Came into Force on April 10, 2002, Volume 2178, p. 179. Available online: https:/ / treaties. un.org/pages/ViewDetails.aspx?src=TREATY\&mtdsg_no=XVIII-11\&chapter=18\&clang=_en (accessed on 24 April 2017).

US Customs and Border Protection. 2018. At Ports of Entry. Available online: https://www.cbp.gov/bordersecurity/ports-entry (accessed on 26 April 2017).

U.S. Department of Justice, Office of Justice Programs, and National Institute of Justice (NIJ). 2019. “Terrorism," which gives two other definitions of terrorism, the U.S. Department of State's definition and the Federal Bureau of Investigation's definition of terrorism. Available online: https://www.nij.gov/topics/crime/ terrorism/Pages/welcome.aspx (accessed on 17 April 2017).

U.S. Department of State, Bureau of Counterterrorism, and Foreign Terrorist Organizations. n.d. Available online: https:/ / www.state.gov/j/ct/rls/other/des/123085.htm (accessed on 17 April 2017).

USLegal. n.d.USLegal.com. Ratio Decidendi Law and Legal Definition. Available online: https://definitions. uslegal.com/r/ratio-decidendi/ (accessed on 1 June 2018).

US State Department. 2015. Bureau of Counterterrorism and Countering Violent Extremism, Country Reports on Terrorism 2015 Report, Chapter 1: Strategic Assessment. Available online: https:/ / www.state.gov/j/ct/rls/ crt/2015/257513.htm (accessed on 26 April 2017).

Uwe, Steinhoff. 2005. The Ethics of Terrorism. In Ethics of Terrorism $\mathcal{E}$ Counterterrorism. Edited by Georg Meggle. Frankfurt: Ontos, Verlag. Available online: https://books.google.co.uk/books?id= DnOG78j31ZUC\&pg=PA78\&lpg=PA78\&dq=Terrorism+and+Counterterrorism:+A+Moral+Assessment\& source=bl\&ots=qfrRCRgqh8\&sig=n-inN15Zu0fXeMpReHWJ30u1yfk\&hl=en\&sa=X\&ved=0ahUKEwi6gfUssDTAhXnCMAKHZksC2kQ6AEIQjAG\#v=onepage\&q=Terrorism\%20and\%20Counterterrorism\%3A\% $20 \mathrm{~A} \% 20$ Moral\%20Assessment\&f=false (accessed on 25 April 2017). 
Vladeck, Stephen I. 2017. The Supreme Court, the War on Terrorism, and the Separation of Powers. Human Rights Magazine. American Bar Association, Winter 2011. Available online: https:/ / www.americanbar.org/groups/crsj/publications/human_rights_magazine_home/human_ rights_vol38_2011/human_rights_winter2011/supreme_court_war_on_terrorism_separation_of_powers / (accessed on 9 February 2019).

Walker, Clive. 2008. The Legal Definition of 'Terrorism' in United Kingdom Law and Beyond. Public Law 352. Available online: https://www.researchgate.net/publication/228214848_The_Legal_Definition_ of_ \T1 \textquoterightTerrorism $\backslash \mathrm{T} 1 \backslash$ textquoteright_in_United_Kingdom_Law_and_Beyond (accessed on 3 June 2018).

Walker, Clive. 2014. Blackstone's Guide to the Anti-Terrorism Legislation, 3rd ed. Oxford: Oxford University Press, p. 10.

Weimeng, Yeo. 2017. Four trends in global terrorism threats in 2017. The Strait Times, January 10. Available online: http:/ / www.straitstimes.com/opinion/four-trends-in-global-terrorism-threats-in-2017 (accessed on 26 April 2017).

Williams, Lynn M., and Susan B. Epstein. 2017. Overseas Contingency Operations Funding: Background and Status. Congressional Research Service, February 7. Available online: https://fas.org/sgp/crs/natsec/R44519.pdf (accessed on 25 April 2017).

Wilson, Scott, and Al Kamen. 2009. 'Global War on Terror Is Given New Name. The Washington Post, March 25. Available online: http://www.washingtonpost.com/wp-dyn/content/article/2009/03/24/ AR2009032402818.html (accessed on 25 April 2017).

Worldatlas World Facts. 2019. Worst Terrorist Attacks in World History. Available online: http:/ /www.worldatlas. com/articles/worst-terrorist-attacks-in-history.html (accessed on 10 February 2019).

Worst Terrorist Strikes—Worldwide. 2017. Compiled by Wm. Robert Johnston, Updated 2 January. Available online: http:/ / www.johnstonsarchive.net/terrorism/wrjp255i.html (accessed on 22 March 2017).

(C) 2019 by the author. Licensee MDPI, Basel, Switzerland. This article is an open access article distributed under the terms and conditions of the Creative Commons Attribution (CC BY) license (http://creativecommons.org/licenses/by/4.0/). 